\title{
Growth models and female labor in post-socialist Eastern Europe
}

Dr Sonja Avlijaš

Research Fellow

Laboratory for Interdisciplinary Evaluation of Public Policies (LIEPP)

Sciences Po

27, rue Saint-Guillaume | 75337 Paris Cedex 07, France

Email: sonja.avlijas@sciencespo.fr

ORCID ID: 0000-0003-3270-0039

\section{Acknowledgements}

This work is supported by a public grant overseen by the French National Research Agency (ANR) as part of the "Investissements d'Avenir" program LIEPP (ANR-11-LABX 0091, ANR-11-IDEX 0005-02). I am very grateful to Bruno Palier, Sarah Ashwin and participants in various seminars and conferences for their useful comments and suggestions.

\footnotetext{
ABSTRACT

Eastern European women had the highest labor force participation in the world during socialism. With the onset of capitalism, significant shares of women permanently exited the labor market in some countries, while they stayed economically active in others. This article shows that the countries' different capitalist growth models - defined as strategic national approaches to growth stimulation and job creation - explain this divergence. Non-linear interactions between national growth models and structuring of female labor are theoretically abstracted in this article, following which they are tested empirically, using a statistical dataset that covers twelve Eastern European countries between 19972015.
} 


\section{INTRODUCTION}

This article is concerned with how capitalist transformation impacts female labor. Using the case of Eastern Europe, it identifies the mechanisms through which capitalist growth models have affected the structuring of the female labor force since the collapse of socialism. Following political economy literature on capitalist diversity (Hall and Soskice 2001; Amable 2003; Thelen 2014; Baccaro and Pontusson 2016), growth models are conceptualized as economic specializations and complementary institutional reforms that countries pursue to stimulate growth and create jobs. While we know that different growth models have emerged in Eastern Europe since the demise of socialism (Bohle and Greskovits 2012), their effects on female labor have not yet been explored. As these interactions have not been examined in other contexts either, this article that focuses on Eastern Europe constitutes a pioneering scholarly effort to theorize and empirically test the relationship between the two phenomena.

Eastern Europe is a salient case study for researching the impact of economic restructuring and its complementary institutional reforms on labor market dynamics, as it allows us to observe capitalist transformations and emergence of market economies in fast forward mode. Moreover, the region's high female labor force participation during socialism stood out in comparison to capitalist economies that were at similar or higher levels of economic development (Figure 1). Socialist countries placed a strong emphasis on female work and promotion of dualearner families (Chase 1995; Lobodzinska 1995). Apart from the ideological commitment to gender equality, economic activation of women and their entry into industrial labor was of enormous economic importance for socialist Eastern Europe in the post-war era, given the exceptionally high death toll of its population, and especially men, during World War II (e.g. Poland lost seventeen percent of its population). Female employment was particularly high in the Visegrad countries-about ninety percent of working age women in Czechoslovakia, Hungary, and Poland were employed during the 1980s (World Bank 2011, 348).

Figure 1

Female labor force participation by region and decade 


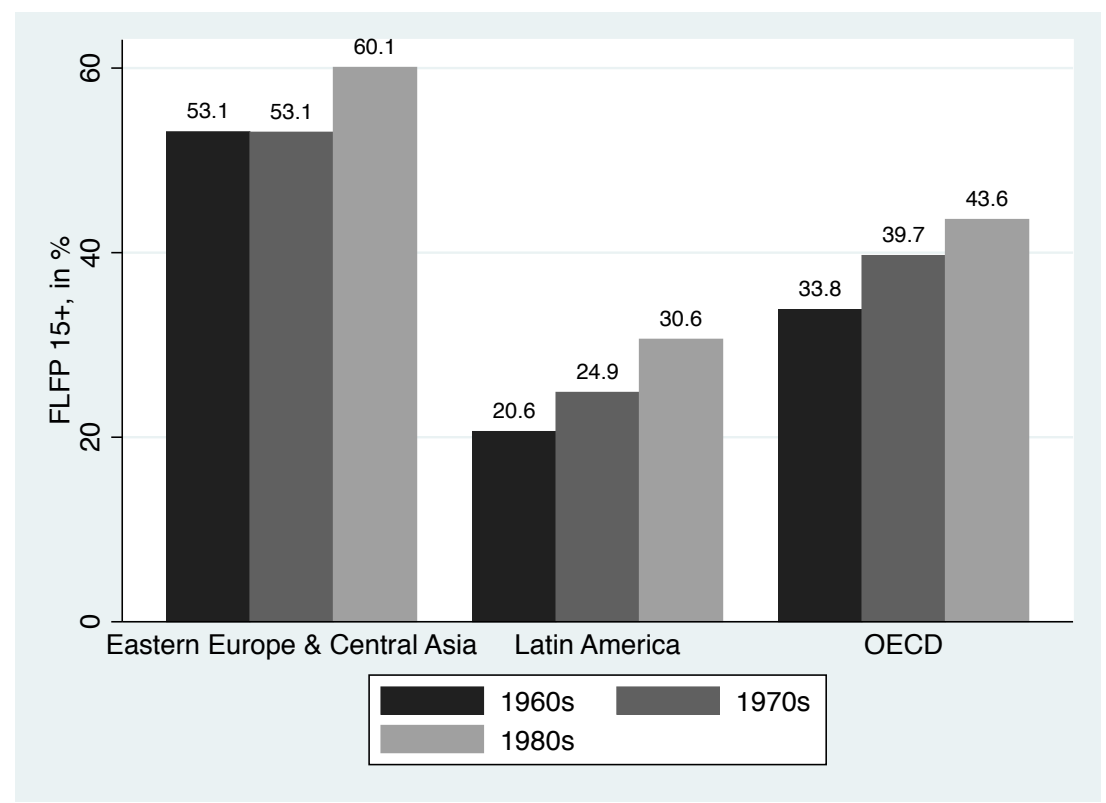

Source: Author's calculations based on data from the ILO Laborsta database.

Notes: 1) Central Asia is included with Eastern Europe since statistics are not disaggregated by the Soviet Republics. 2) Data does not contain all years nor all countries, especially for EECA (Belarus, Bulgaria, Czechoslovakia, Estonia, Germany GDR, Hungary, Latvia, Lithuania, Moldova, Poland, Romania, USSR and Yugoslavia are included). 2) Latin American data excludes Caribbean islands.

The transition to capitalism, triggered by the fall of the Berlin Wall in 1989, initially had a strong negative impact on women's, along with men's, labor force participation across the entire region (Figure 2). The lowest levels of women's participation could be observed around year 2000, approximately ten years into these countries' market transitions (Figure 3). Since then, some of the countries have successfully reintegrated both women and men into their labor markets, while the gap between the recovering male and stagnant female labor force participation has remained large in others.

Figure 2

Change in activity rates by gender in selected transition economies, 1985-1997 


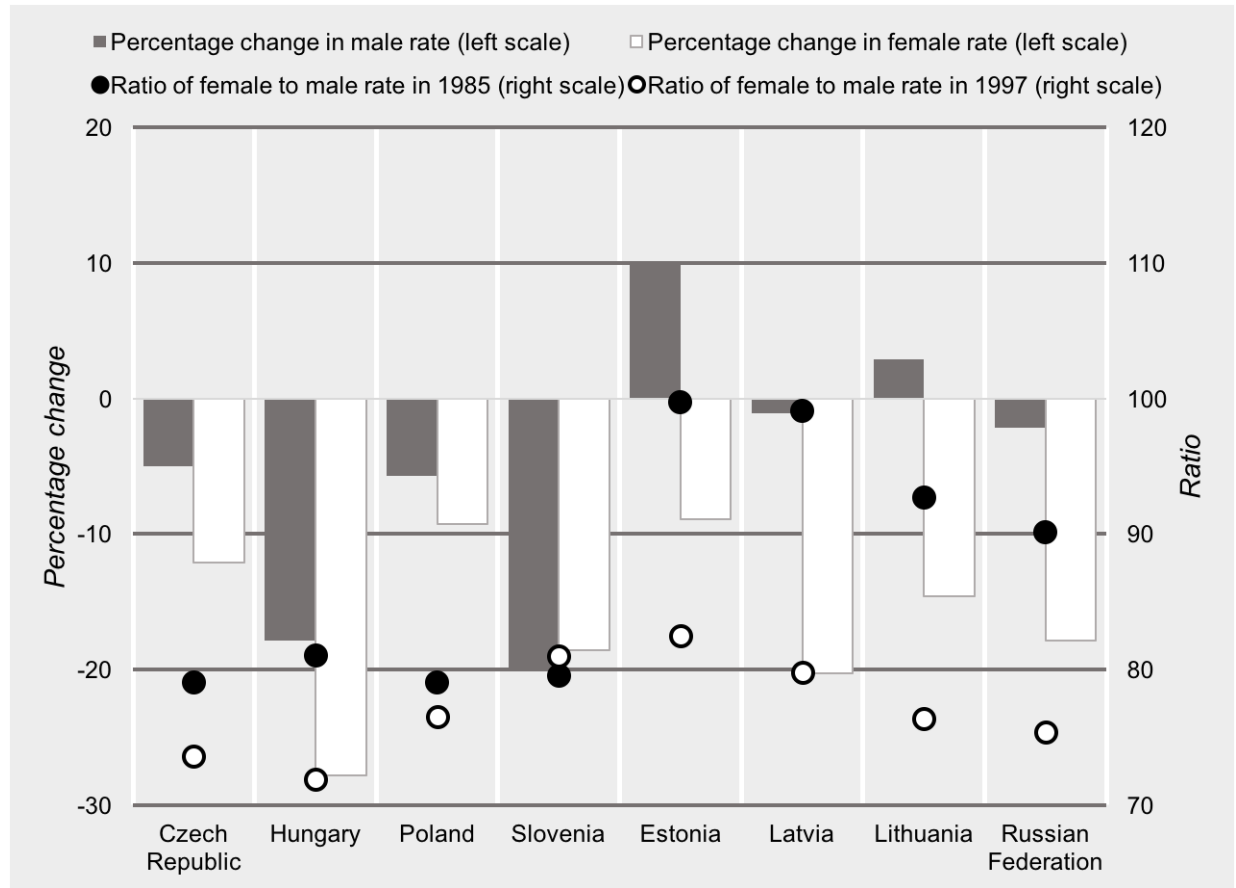

Source: United Nations Economic Commission for Europe secretariat estimates, based on national labor force surveys, statistical yearbooks and direct communications from national statistical offices.

Specifically, the Baltic countries saw a substantial economic re-activation of women since the early 2000s. By the end of 2015, labor force participation of working age women (aged fifteen to sixty-four) in both Estonia and Latvia stood at seventy-three percent, while the gender gap in participation amounted to between six and seven percentage points. In Visegrad countries, which are at a similar level of economic development, lower female labor force participation has persisted. At sixty-two percent and sixty-one percent respectively, Hungary and Poland had particularly low rates by 2015 (Figure 3). Their gender gaps in participation stood at thirteen percentage points in 2015 in both countries. Moreover, the 2008 economic crisis only had a shortterm impact on female employment levels, following which the rates quickly recovered in the Baltic, while they continued to lag in Visegrad. This post-crisis continuation of cross-national divergence in female labor force participation indicates its persistent character.

\section{Figure 3}

Female labor force participation in Visegrad and the Baltic, 1997-2015 


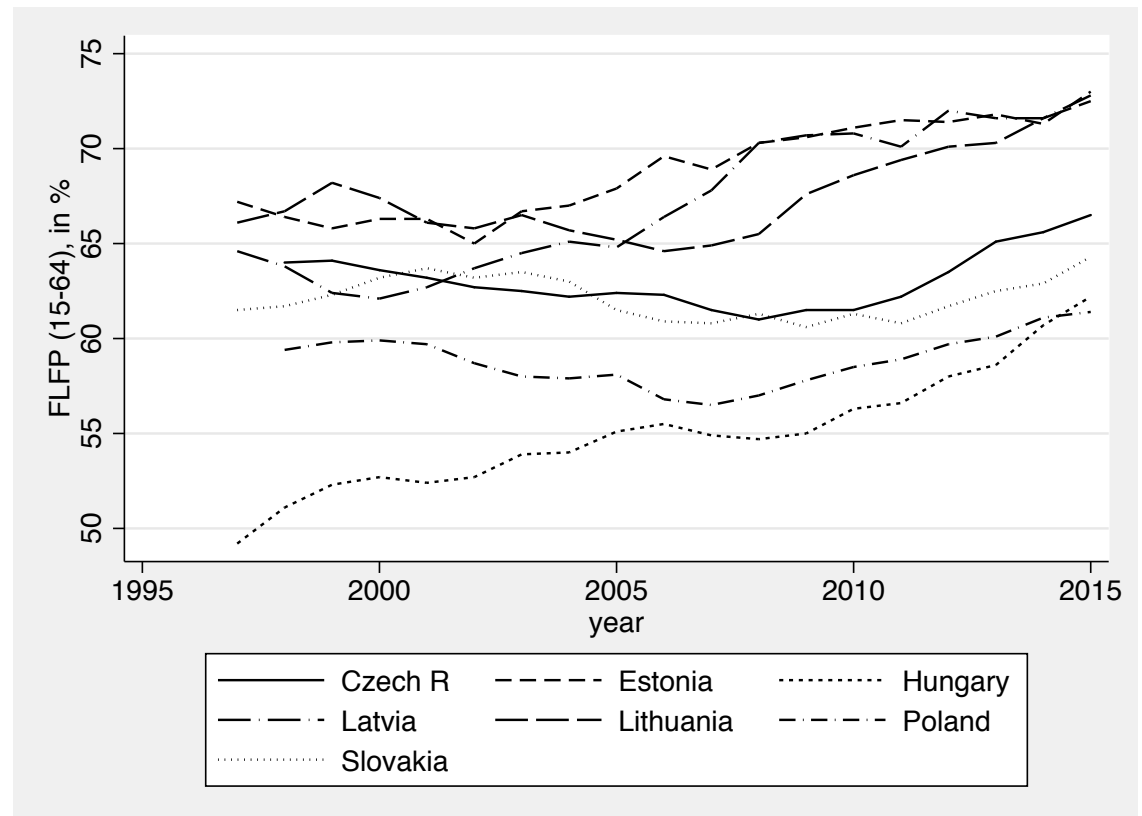

Source: Eurostat.

High female labor force participation is an important policy goal in the European Union (EU) and beyond. Reasons for this are several, including equality of opportunity between the genders, sustainability of pension systems and optimal allocation of economy-wide resources. By arguing that economic restructuring and associated policies affect female work opportunities, this article expands EU-level policy recommendations associated with the Lisbon Strategy and Europe 2020, which have thus far almost exclusively focused on work-life reconciliation policies to address the phenomenon of low economic activation of women. Since jobless growth during post-socialist transition has already widely refuted Say's law that abundant labor supply creates its own demand, this article extends that logic to women by showing that they work when jobs are available. It subsequently concludes that policies which aim to increase the supply of women to Eastern European labor markets, by for example reducing their childcare responsibilities, are not enough to activate women, and that a concurrent stimulation of demand for female labor is also necessary.

This article adopts a theory-oriented mode of explanation. The theory-oriented explanation focuses on illuminating the precise theoretical mechanism through which relevant variables cause certain outcomes that can then be empirically tested. This implies that non-linear interactions between national growth models and structuring of female labor are first 
theoretically developed and abstracted in the article, following which they are tested empirically, using a statistical dataset that covers twelve Eastern European countries during the period 19972015. Such a mode of explanation can be contrasted to the historically specific, which aims to provide a complete explanation of why a phenomenon occurred in a certain context, and the multivariate, which focusses on identifying a small set of variables that have a measurable impact on a broad class of events (Hall 2006, 25).

The article adheres to the following structure. The next section offers a review of interdisciplinary theoretical and empirical literature on capitalist diversity, growth models and female labor force participation, from both advanced capitalist economies and Eastern Europe. The theory of reactive structuration of female labor that this article puts forward is then presented, following which it is tested empirically. The final section summarizes results of the statistical analysis, and discusses their theoretical and empirical implications.

\section{LITERATURE REVIEW}

\section{CAPITALIST DIVERSITY AND FEMALE LABOR}

There is a growing scholarly interest in the profound global economic transformation that has taken place over the past three decades. This transformation refers to the changing distribution of workforce across economic sectors at the backdrop of largescale processes such as globalization, expansion of the service economy, and the information and communication technology (ICT) revolution. Feminist economic and social policy literature have concluded that competitive demands of this new economy and the different ways countries respond to them provide important insights for explaining cross-country differences in female labor market outcomes (McCall and Orloff 2005, 160). Academic interest in understanding the demand for female labor is thus growing. Humphries and Sarasúa (2012) capture the spirit of this emerging trend by reminding us that women have historically always worked when jobs have been available. It is thus no longer sufficient to exclusively focus on the drivers of female labor supply, if we are to understand why women are more economically active in some countries than in 
others.

Literature has shown that different sectors of the economy are characterized by different patterns of female employment. This is because sex-based segregation by sectors of employment has been historically pervasive across the world (Bettio and Verashchagina 2009, 7). While manufacturing was traditionally seen as reducing women's opportunities in the old industrial countries, evidence from emerging markets has offered a more varied picture. Production of goods, especially in light industries of the global South such as textiles, has been shown to stimulate demand for female labor (Elson and Pearson 1981). On the other hand, recent evidence indicates that economies which are based on the more capital intensive and technologically sophisticated industry display a negative correlation between manufacturing and female work (Tejani and Milberg 2016). These findings imply that the more complex the industrial sector, and the more industrial upgrading takes place, the less women work in it.

The effect of transition to the service economy has had a more straightforward positive effect on female economic activity. The emergence of white-collar service sector has generated attractive, non-stigmatizing types of jobs for women (Gaddis and Klasen 2014). As a growing number of women entered the labor market, market demand for services that were previously provided at home began to grow, further fueling the expansion of female employment (Huber and Stephens 2000). Since women have surpassed men in many aspects of educational attainment, the development of ICT has further benefited them through increased employment opportunities in the expanding knowledge-based service economy (Nelson and Stephens 2013; Wren et al. 2013).

Comparative political economists have complemented these insights on the impact of economic restructuring on female labor with reflections on how specific institutions may reinforce these trends. The Varieties of Capitalism analytical framework has connected different production regimes- manufacturing vs service based ones-to the countries' skill regimes and welfare states which underpin and complement them (Hall and Soskice 2001; Amable 2003). The framework was then gendered through the argument that specific skills regimes, ${ }^{1}$ a feature of 
countries which specialize in manufacturing, are inclined to exacerbate disparities based on the gendered division of labor, in the sphere of both paid work (Estevez-Abe 2005; Estevez-Abe 2006) and household work (Iversen et al. 2005). In contrast, general skill regimes, a feature of countries which have a comparative advantage in high-tech and services, are seen to foster greater class disparities and weaker gender disparities as they hire more women. Likewise, welfare states which favor the male-breadwinner model have been associated with compensation of women as mothers and wives, rather than workers, thus stimulating their labor market inactivity. These welfare states mostly exist in countries which have specific skill regimes and predominantly male manufacturing labor, such as Germany (Sainsbury 1999).

The next generation of comparative political economy scholarship added the role of the state to this enquiry, by identifying government actions which have served to adapt the countries' economic systems to the challenges of the new economy. Morel et al. (2012) discuss a reorientation of social policy in the post-industrial era toward the social investment state. Social investment in human capital of the disadvantaged citizens, including women, has seemingly allowed these segments of the population to access higher wages and better quality jobs. These policies are an integral part of the countries' growth strategies, because they boost both individual and national levels of productivity. They have also had positive effects on female work. Thelen (2012) has associated the growing demand for female labor in the ICT-driven postindustrial economy with social investment oriented state policies. Specifically, she argues that state provision of education, training, and active labor market policies, which she observes in Scandinavia and the Netherlands, have led to a reduction of gender inequality in the labor market. Nelson and Stephens (2013) show that public investment in school and college-based education is linked to high levels of female knowledge-intensive service employment while low spending on active labor market policies has a negative effect on female employment.

Most recently, political economy literature has recognized an important overall role of the state in supporting a country's trajectory of economic growth in the modern era by implementing specific educational and welfare reforms which adapt it to changing global 
economic conditions, driven by technological change, globalization, and financialization (Avlijas et al. forthcoming; Hassel and Palier forthcoming). Gender effects of these broader economic transformation trajectories, and the associated policy reforms, have not yet been examined.

\section{CAPITALIST DIVERSITY IN EASTERN EUROPE}

Eastern European countries have gone through extensive reforms of their economies since the early 1990s. Comparative political economists have identified two main trajectories of capitalist transformation in the region: one based on re-industrialization and industrial upgrading, which has taken place in Visegrad, and the other based on the expansion of the service economy, which has taken place in the Baltic (Feldmann 2006; Nölke and Vliegenthart 2009; Bohle and Greskovits 2012). Expansion of the service economy in the Baltic has additionally been ICT-based and knowledge-intensive, and underpinned by extensive state investment in human capital (Runnel et al. 2009; Avlijas 2019). There have been no attempts so far to examine the implications of these post-socialist growth models for gender relations in the labor market.

Institutions and policies that have underpinned these different growth models in Eastern Europe were to a large extent determined by the region's high dependency on foreign sources of capital and innovation, and its preparation for EU membership. A global race to attract foreign sources of capital drove Eastern European corporate tax rates to very low levels (Appel 2011). Moreover, the requirements of the EU's Stability and Growth Pact (SGP), which defined an excessive budget deficit as one greater than three percent of gross domestic product (GDP) left little room for fiscal maneuver.

To attract foreign direct investment (FDI), Visegrad countries in particular offered generous incentives to large transnational employers, such as tax breaks, cheap real estate, local subsidies for employee training and custom-free zones (Bohle and Greskovits 2006, 12). These industrial subsidies strained their public purse further. To ensure political stability, which was also an important tool for protecting foreign investors' interests, Visegrad countries paid out substantial non-employment benefits to the losers of transition, such as unemployment and early 
retirement schemes, which represented a large item of their expenditures (Vanhuysse 2006). They were therefore severely fiscally constrained throughout their transition to capitalism, and had very limited resources to invest in new social risks and educational expansion, even during the periods of high growth.

Furthermore, it appears that the multinational companies were content with the existing level and type of specific skills in Eastern Europe that were available for industrial production, which is why they came to the region. Nölke and Vliegenthart (2009) highlight that neither multinational companies nor governments in Visegrad countries have invested much in further qualifications of their workforce (680). Bohle and Greskovits (2012) argue that the absence of educational reform and expansion in Visegrad countries can also be attributed to these scarce resources following pressures to attract foreign investors with subsidy packages, as well as EUimposed tight budgetary constraints. Nevertheless, Tarlea (2015) shows that demand for tertiary education in Visegrad countries has risen over the past few years, and that it has been predominantly shaped by the growing skill needs of multinational companies, which offer better wages than the rest of the economy. Despite this recent progress, rates of tertiary educational attainment in Visegrad have remained at significantly lower levels than in the Baltic countries, which have made much more significant progress in terms of educational attainment since the collapse of socialism.

The Baltic countries, on the other hand, were less attractive for foreign investors than their Visegrad counterparts as far as their industrial capacity was concerned. Nevertheless, their knowledge-intensive service economy did not materialize out of nowhere; the state played a key role in the production of human capital which was an important input for the development of knowledge-intensive services (Avlijas 2019). Baltic countries' educational reforms were thus geared toward the role of education in strengthening their international competitiveness as exporters of knowledge-intensive services. Estonia, most notably, has demonstrated stellar performance in terms of educational achievements, superseding all other Eastern European countries. For example, the country's 15 year olds were ranked third in the world by educational 
excellence, after Singapore and Japan, by the 2015 PISA-Program for International Student Assessment (OECD 2016). Moreover, while the Baltic countries did little in terms of direct financial compensation of the losers of transition, all three have implemented active labor market policies since the early 2000s. They have also had more generous unemployment assistance coverage and income replacement rates than the Visegrad countries (Avlijas 2019). This implies that a relatively strong labor market policy has underpinned their growth models.

\section{THEORY OF REACTIVE STRUCTURATION OF FEMALE LABOR}

The literature reviewed in the previous section has shown that it is possible to establish an association between capitalist diversity, i.e. countries' growth models, and female work. These static snapshots of the relationship between a country's production regime, its educational and social protection systems, and female work, such as those offered by Estevez-Abe (2005; 2006), however, need to be updated vis-à-vis the dynamics of the new economy, and challenges such as deindustrialization, and the digitalized service economy. We also do not know how these challenges unfold in the context of emerging market economies such as the Eastern European ones, and why some of these countries have struggled with reintegration of women into the labor force despite a strong legacy of female work during socialism, while others have not.

These literature gaps and the growing scholarly interest in understanding the demand for female labor form the basis of the theory of reactive structuration of female labor that this article puts forward. The theory argues that countries' growth models, i.e. their efforts to stimulate growth and job creation via economic specialization and complementary institutional reforms, are important determinants of female economic participation. The name of the theory stems from the proposition that the pattern of female labor force participation that we observe across Eastern Europe is a reaction to the dynamics of capitalist economic restructuring and the associated policies. Given that we do not see an overall improvement in 
female economic activation, but its reduction in certain contexts and its increase in others, the described process is referred to as structuration, instead of restructuration, which would etymologically imply superior outcomes in all cases. The theory posits two stylized, mutually exclusive mechanisms through which a country's growth model can affect female labor force participation: i) the vicious cycle, and ii) the virtuous cycle.

The vicious cycle mechanism posits that re-industrialization and industrial upgrading, along with the policies that have been implemented to support these processes, can be associated with a defeminization of manufacturing employment and a more general withdrawal of women from the labor force. In contrast, the virtuous cycle suggests that ICT-based and knowledgeintensive expansion of the service economy and the human capital oriented policies that have underpinned it can be associated with higher female labor force participation. The cogs and wheels through which the two mechanisms operate are detailed below.

The re-industrialization oriented growth model is based on FDI-led privatization and restructuring of large state-owned enterprises. Due to the very rapid trade liberalization and high dependency on foreign capital, price competition on industrial exports became the key competitive basis. However, given the relatively high educational attainment of the population that was inherited from socialism, re-industrialization was based on technological upgrading and middle- and high-skill, rather than low skill jobs. Therefore, while the restructuring of the economy required flexibilization of the labor market, the need to preserve workers' industrial skills has reduced demand for educational reform and expansion. As productivity gains in the restructured economy were achieved through substantial labor shedding, these 'losers of transition' were protected using fiscally expansive social protection strategies, such as severance pay and early retirement, which has further reduced their demand for requalification and educational reform. State resources were further squeezed by industrial subsidy expenditures to attract FDI, global tax competition which reduced tax revenues, and the EU SGP. These severe fiscal constraints amid political pressures to compensate job losers have made it difficult to redirect state resources toward new social risks, youth policy, social investment, and educational 
reform, which further stalled the development of ICT-driven knowledge-intensive services.

Given the high numbers of women who worked in manufacturing during socialism, I posit that defeminization of manufacturing employment has taken place during re-industrialization because male labor-intensive manufacturing sectors were upgraded while female labor-intensive ones were not. Those who lost their jobs in the restructuring received passive cash compensation instead of opportunities for re-qualification and enhancement of their human capital. This would have amplified the negative impact of industrial upgrading on women, since their opportunities for employment in manufacturing were disproportionately decreasing as transition progressed, while the expansion of the new service economy was stifled due to the reasons discussed above. Expansion of tertiary education is also a more important factor for women than for men in the region because women have higher qualifications than men in the same category of jobs, possibly due to the higher barriers to labor market entry that they face (Avlijaš et al. 2013).

The tertiarization oriented growth model, in contrast, is based on rapid liberalization and macroeconomic stabilization to attract foreign capital in dynamic service sectors such as banking, telecommunications and real estate. This model is centered around exports of high value services, as well as substantial domestic consumption in telecommunications, finance and retail. An emphasis on macroeconomic stability and economic restructuring, amid substantial fiscal pressures from low tax rates, to attract foreign capital, and the negative economic impact of the demise of socialism, required significant cutbacks in social and employment protection. At the same time, state-led development of a dynamic service economy in the era of ICT-led growth required educational reform, expansion of tertiary education and development of general skills. The low employment protection and increasing flexibilization of the workforce, which took place along with rapid liberalization, encouraged workers to invest in general skills which are easily transferable between firms and sectors of the economy, rather than in specific skills. The state also made substantial investment in general skills education to boost the knowledge foundation of its new services oriented growth model. The high flexibility of the workforce, along with growing employment opportunities, and relatively high education levels, reduced the demand for 
social protection. Such a sequence of incentives allowed this growth model to depart from the reindustrialization based one, and redirect some of the resources away from cash compensation, and toward educational reform and social investment.

Based on literature insights that public investment in human capital supports women's entry into the labor force, I hypothesize that countries which pursued educational expansion and state-led investment in human capital saw substantial increases in female labor force participation. I also differentiate this growth model from the one of socially disembedded external devaluation to boost price competitiveness of tradable services, that takes place without concurrent state investment in educational expansion and acquisition of new human capital, and that would lead to inferior outcomes vis-à-vis female labor force participation in comparison to the model discussed here.

Finally, I suggest that these two Eastern European post-socialist growth models have been mutually exclusive. My assumption is that a country following the path of industrial upgrading has not been able to concurrently pursue the development of a dynamic services oriented economy and vice versa. This is because institutional complementarities that support the development of one trajectory are further reinforced by the Eastern European post-socialist context of tight budgetary restraint and dependence on foreign capital. This reduces the agency of domestic actors and makes them particularly path dependent. In other words, policy trade-offs have been in place: those countries which have invested in passive cash compensation of the losers of transition have not been able to simultaneously implement the agenda of educational expansion and investment in human capital, and vice versa.

\section{THE MODEL}

Figure 4 illustrates the proposed relationships between female labor force participation $(\Delta \mathrm{L})$, industrial upgrading $(\Delta \mathrm{K})$, educational expansion $(\Delta \mathrm{E})$, and tertiarization, i.e. services expansion $(\Delta \mathrm{S})$ in a four-quadrant diagram.

The vicious cycle that the model depicts is as follows: Initially, while a country's 
competitive advantage lies in light, labor intensive manufacturing such as textiles, women benefit from manufacturing employment. Starting in the north-east quadrant of Figure 4 a movement down the $f_{1}$ curve takes place and industrial upgrading increases from $K_{0}$ to $K_{1}$. This affects female labor force participation negatively so it decreases from $L_{0}$ to $L_{1}$. This event, ceteris paribus, produces an upward movement along the g curve, depicted in the south-east quadrant, so that $\mathrm{E}_{0}$ shifts to $E_{1}$. The way this shift should be interpreted is that educational reform toward general skills loses support and there is disproportionately more demand for vocational education and specific skills. This shift from $\mathrm{E}_{0}$ to $\mathrm{E}_{1}$ leads to an upward movement along the $\mathrm{h}$ curve so that tertiarization is reduced from $S_{0}$ to $S_{1}$.

Figure 4

Theory of reactive structuration of female labor

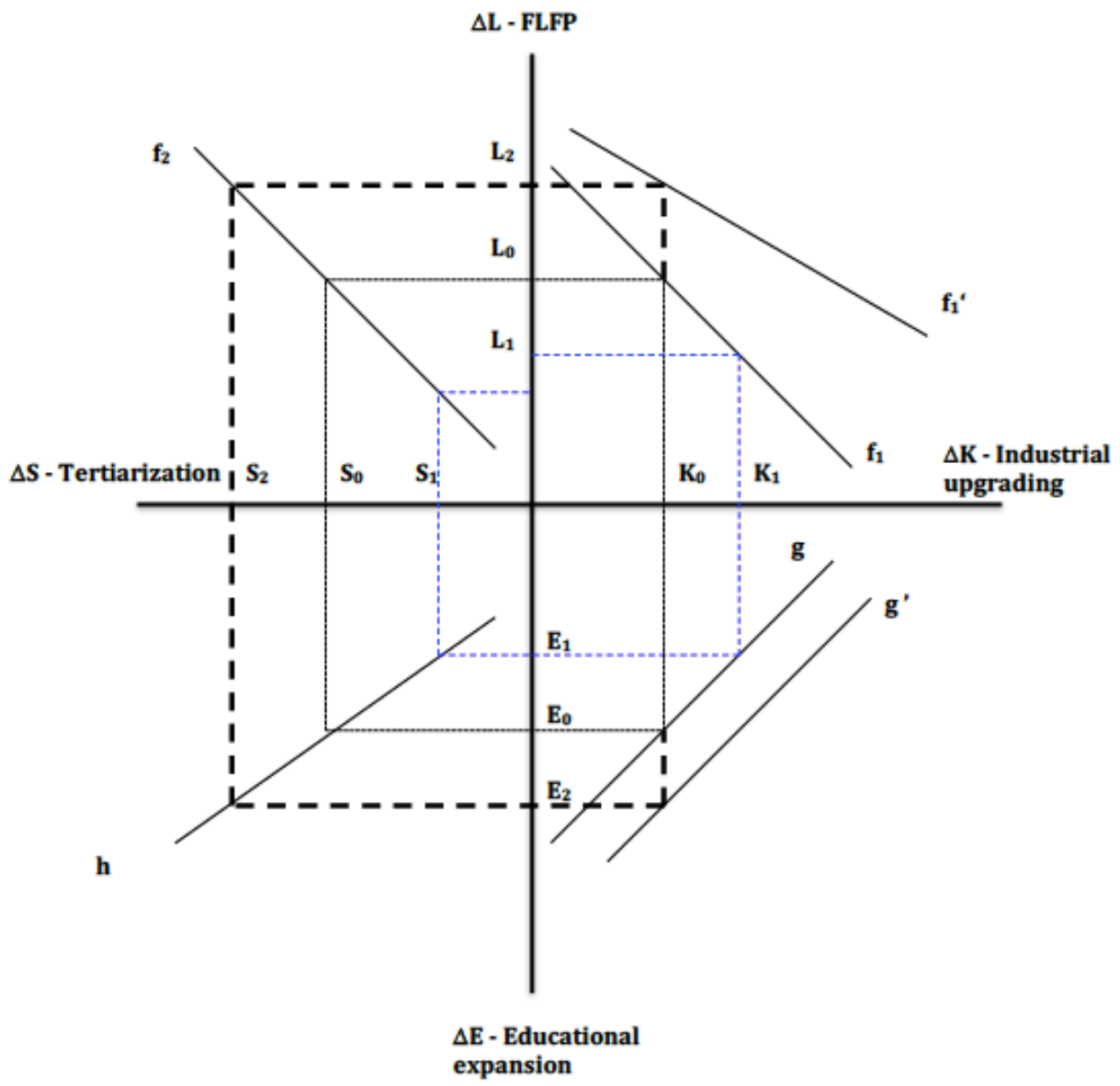

The mechanism whereby there is a reduction in services expansion is as follows: At any 
given level of educational attainment, there is a certain level of tertiarization. If a country wants to stimulate services expansion in the new era of growth, it should invest more in educational expansion. However, as industrial upgrading takes place, there is both more demand for specific skills and fewer resources for educational expansion, so the development of a dynamic service economy stalls while manufacturing jobs become relatively more attractive. This negative loop results in an even lower new equilibrium for $L$. Women do not react to these employment losses politically because collective action is very hard to organize for the unemployed, so women become even further socially marginalized.

The virtuous cycle operates as follows: Stagnation of industrial complexity (or absence of industrial upgrading) puts pressure on a country's economic growth model, so it starts with educational expansion to boost the economy. This is depicted as an outward shift of $g$ to $g$ ' in the south-east quadrant, which occurs due to the exogenous impact of new government spending on education. This shift results in $E_{0}$ increasing to $E_{2}$. This, in turn, increases the level of $S_{0}$ to $S_{2}$, as the role of services in the economy expands, and of $\mathrm{L}_{0}$ to $\mathrm{L}_{2}$, as female labor force participation grows. This growth of female labor force participation results in an outward shift of $f_{1}$ to $f_{1}{ }^{\prime}$ because the relationship between female labor force participation and industrial upgrading is redefined once a larger share of the employed is in the service economy than in manufacturing. In that new structural context, overall female labor force participation will be higher at any level of industrial upgrading. $f_{1}{ }_{1}$ is also less elastic because the link between women's position in the labor market and industrial upgrading is weakened, as the service economy expands and there are more employment opportunities outside manufacturing. Finally, since manufacturing has not been upgraded, low-skilled women continue to benefit from employment in light industry.

\section{HYPOTHESES}

Because of the non-linearity of the theory of reactive structuration of female labor that is presented in Figure 4, and its emphasis on interactions between several independent variables, defining testable hypotheses to empirically verify it is a vexed endeavour. Following a careful 
assessment of data availability in Eastern Europe, I identify the following five interrelated hypotheses to test the most important relationships between the variables that are depicted in Figure 4. If they confirm the directions of the relationships depicted in the figure, they will provide substantial empirical support for the proposed theory.

Hypothesis 1a: Industrial upgrading leads to defeminization of manufacturing employment.

Hypothesis 1b: Tertiarization leads to feminization of services employment.

Hypothesis 1c: Industrial upgrading impedes the expansion of female labor force participation, while tertiarization boosts it.

Hypothesis 1d: Public investment in educational expansion amplifies the effect of tertiarization on female labor force participation.

Hypothesis 1e: Industrial upgrading impedes public investment in educational expansion, which amplifies the negative effect of industrial upgrading on women's labor force participation.

\section{EMPIRICAL ANALYSIS}

\section{DATA, OPERATIONALIZATION, AND METHODS}

I use statistical analysis to test the hypotheses on a sample of twelve Eastern European countries during the period 1997-2015. These 19 years are the longest period for which most of the data on the region is available. I run OLS estimates with panel corrected standard errors (PCSE), following an influential article by Beck \& Katz (1995) on how to analyse time-series cross-section datasets. PCSE OLS estimates are said to be more realistic because of their larger standard errors. If the coefficients remain significant when applying this method, the results can be treated as sufficiently robust. Fixed effects are applied in the estimates, so that average changes over time within countries in the sample, by controlling for time invariant country specific effects. This is because, following comparative political economy scholarship, I am more interested in comparing average changes within individual countries over time than in average cross-country effects (Shalev 2007, 264). 
To facilitate comparison between the countries, I use the least squares dummy variable estimator (LSDV) to visualize results of the fixed effects estimates. This is an alternative method that produces identical results as the OLS, but that also generates specific coefficients for each country, which can be illustrated on a graph. Finally, I also use marginal effects to estimate the impact of interaction of the different factors on the dependent variable-female labor force participation.

Labor market data, which are used to perform these analyses, are obtained from Eurostat. Eurostat's data on female labor force participation and employment by sectors of economic activity are based on household level Labor Force Surveys. Data on employment in services include all public services (public administration, education, health and social services), high productivity private services, such as financial intermediation, real estate and transportation services, and low productivity services, such as wholesale and retail trade, and hotels and restaurants.

Because of the variation in employment-to-population ratios across the countries in my sample, and following Gaddis and Klasen (2014), I measure employees in a specific sector as a share of the total working age population, rather than their share in total employment. This is because two countries can have identical shares of employees in manufacturing out of all employees, but when the overall employment-to-population ratio is much lower in one country, that indicator hides the fact that a significantly lower portion of working age people work in manufacturing in that country. The additional benefit of using this specification of the variables is that it accounts for the full variation in gender gaps in labor force participation, which are not always fully compatible with the variation in female labor force participation.

Since Eastern European countries only started becoming members of the EU since 2004, some of the economic data is not available for all countries for the entire period of observation. I thus obtain the share of services in value added (as a percentage of GDP) from The World Bank's World Development Indicators database, and use it as a proxy for the extent of tertiarization, i.e. services expansion, in an economy. 
As a measure of industrial upgrading, I use the Economic Complexity Index (ECI) constructed by Hausmann et al. (2011). The basis for ECI is the quantity and complexity of exported goods and the frequency of exports. Services and non-export goods are not included in the index. This index was developed because of the inadequacy of existing measures to capture the different components of industrial upgrading, and Hausmann et al. (2011) have already used it in econometric models which estimate structural change and economic growth.

When it comes to educational reform toward general skills and more comprehensive tertiary education, there is no agreement in the literature on how to measure the extent of general or specific skills in an economy. Several indicators have been used to determine a country's skill regime while the human capital literature has focused on the quantification of educational attainment (Martinaitis 2010). Because specific skills are associated with vocational training while general skills are associated with tertiary education, using measures such as the share of the total population, and the share of women with tertiary educational attainment, can also act as approximations of general skills education. Nelson and Stephens (2012) measure social investment in education by levels of tertiary educational attainment and educational expenditures. This is also why I use the term educational expansion although I am interested in the shift toward greater provision of general skills, as opposed to specific ones. I also analyze the share of spending on education as a percentage of GDP because I assume that Eastern European countries which inherited specific skill regimes from socialism had to invest more in their education to reorient their educational systems toward general skill regimes. Nevertheless, Castelló-Climent and Hidalgo-Cabrillana (2012) warn of the difficulty of drawing conclusions from data on educational expenditures, because such numbers suffer from substantial interpretational problems. For example, countries vary according to their demographics, so countries that educate more usually spend less on a per capita basis. Therefore, I do not include a measure of spending per student in my analysis, and I take the results from the analysis of educational expenditures as a share of GDP with a grain of salt. 


\section{RESULTS}

To test Hypothesis 1a, which proposes that industrial upgrading leads to the defeminization of manufacturing employment, I estimate a PCSE OLS model with fixed effects, predicting the share of women in total manufacturing employment on the index of economic complexity (ECI). The model also includes the squared form of ECI to check for the possibility of an inverse U-shaped relationship between economic complexity and the dependent variable, following the literature which shows that women may benefit from industrial upgrading at lower levels of economic complexity (Elson and Pearson 1981; Tejani and Milberg 2016). The model controls for GDP per capita, as a proxy of economic development, although, due to the high correlation between economic complexity and GDP per capita, the estimates may be affected by multicollinearity. I show the results of the estimates with and without the control. Some of the other possible variables that could affect the proposed relationship, such as occupational segregation, are not available for these countries in a time-series format so they are not included. Nevertheless, by including fixed effects, the model controls for all country-specific characteristics that do not vary over time.

The results (detailed in Table A-1 in online supplementary material) are summarized in Figure 5. They support Hypothesis 1a by indicating that increases in economic complexity have led to a defeminization of manufacturing within countries over time. The figure presents the PCSE OLS estimates with fixed effects, using the LSDV method to produce the graph. Estimates suggest a slight positive relationship between the two variables at the lower levels of economic complexity, following which we see a sharp significant fall in the share of women in manufacturing employment along with the growth of economic complexity, both within and across the countries. Results using an alternative measure of defeminization of manufacturing employment further confirm Hypothesis 1a (for details, see Table A-2 and Figure A-1 in online supplementary material).

\section{Figure 5}

Predicted values: \% of women in total manufacturing employment 


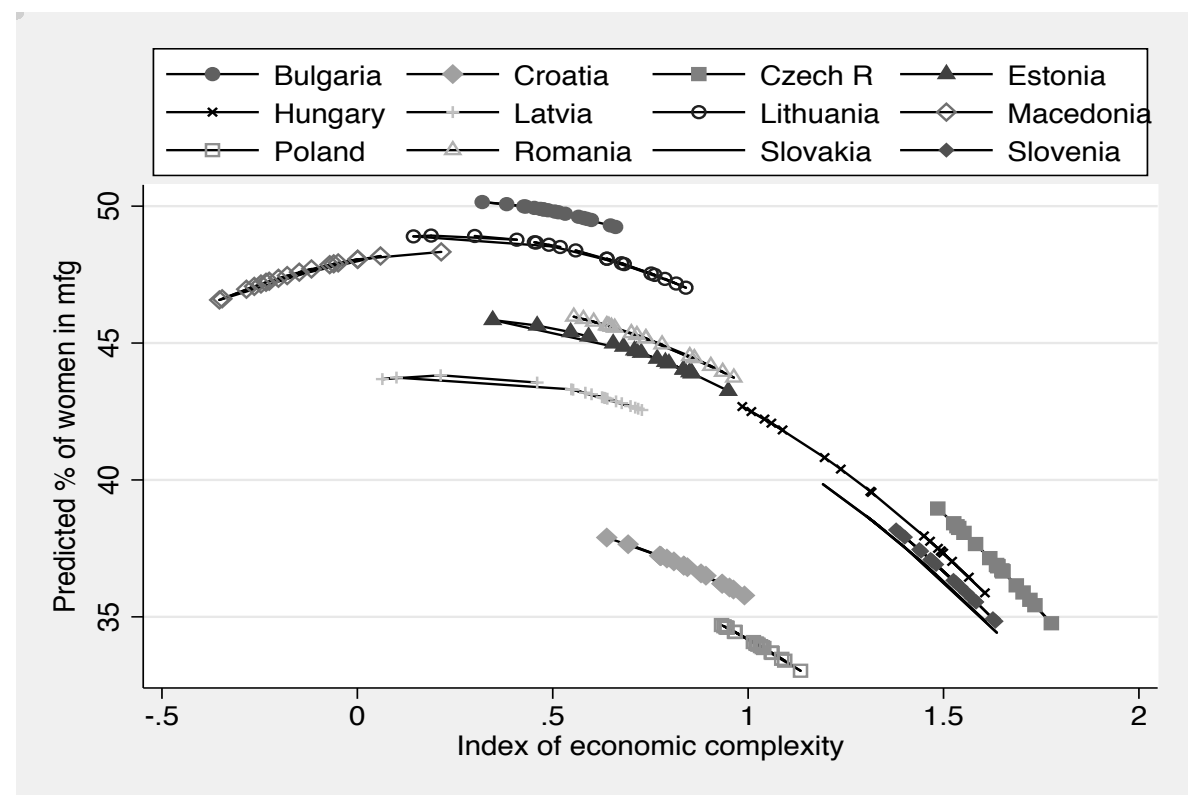

To test Hypothesis 1b, which proposes that tertiarization disproportionately benefits women in comparison to men in terms of their employment opportunities, I estimate a model predicting the share of women in total services employment on the value added of services as a share of GDP. I do not include a quadratic specification of the independent variable because there is no theoretical reason to expect a quadratic relationship. The model controls for GDP per capita as a proxy for the level of economic development. By including fixed effects, the model also controls for all country-specific characteristics that do not vary over time.

\section{Figure 6}

Predicted values: share of women in total services employment 


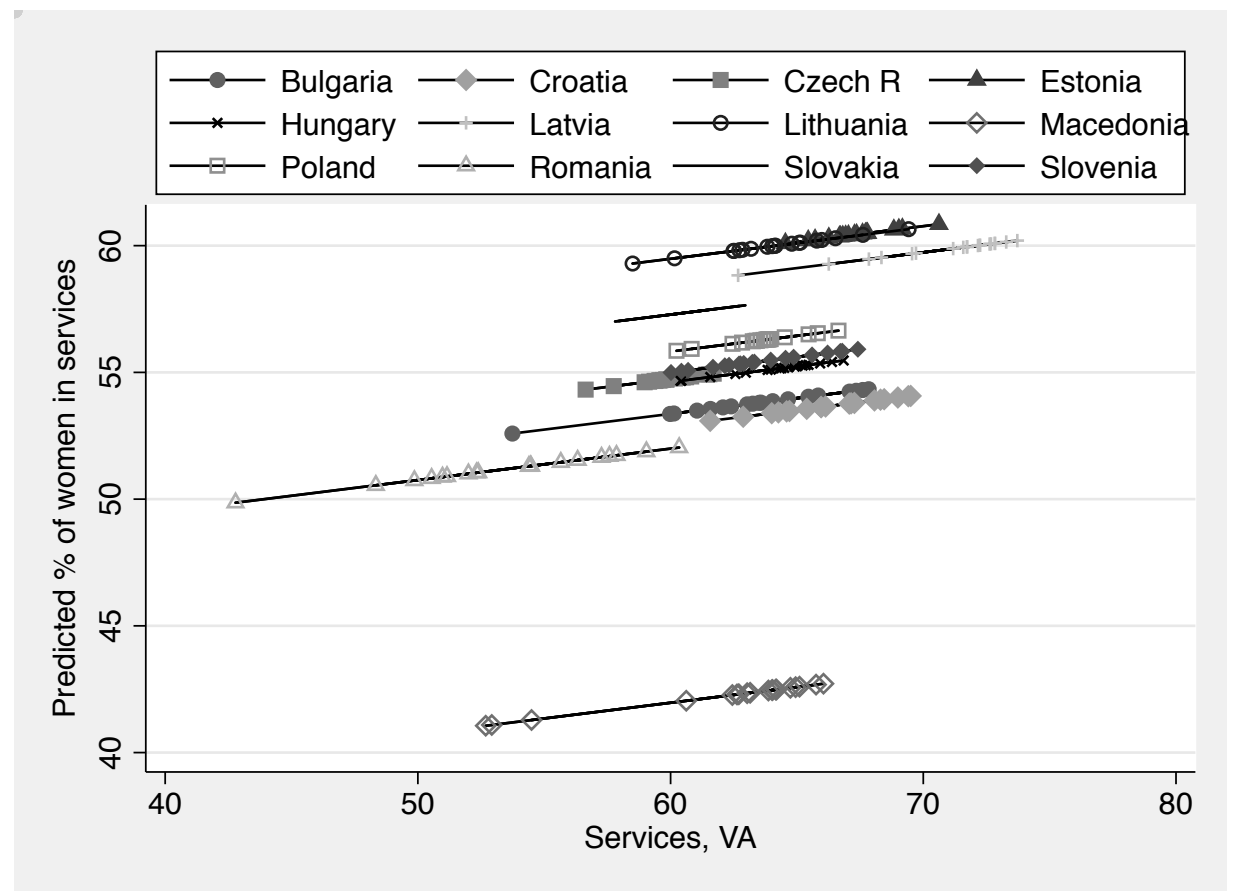

The results (detailed in Table A-3 in online supplementary material) are summarized in Figure 6 and they support Hypothesis 1b. The fixed effects PCSE OLS estimates are significant and they indicate that growth of services in value added can be associated with the growing share of women in services employment, in comparison to men, i.e. with feminization of services employment, both across and within the analyzed countries. Therefore, I conclude that women have disproportionately benefited from the creation of service jobs in Eastern Europe, so that feminization of the sector was higher in those countries where the sector's expansion was more substantial. Results using an alternative measure of feminization of employment in the service economy further confirm Hypothesis $1 \mathrm{~b}$ (for more details, see Table A-4 and Figure A-2 in online supplementary material).

At the same time,

Figure 6 indicates that some countries have had lower levels of female employment in services at the same levels of tertiarization. This can be observed although female employment in services has been increasing in all countries, along with the growth of their share in value added. For example, a comparison between Lithuania and Poland in

Figure $\boldsymbol{6}$ indicates that their shares of services in value added are at around the same level, while their shares of women in services employment are at around sixty and fifty-five percent respectively. The difference between the two is even more pronounced when we compare female employment rates in services in the two countries (Figure A-2 in online supplementary material). 
While the female services employment-to-population ratio in Poland has reached a maximum of twenty percent, it has reached a maximum of fifty percent in Lithuania, at almost identical shares of services in value added.

Such stark differences in female employment in services between the countries speak in favor of the proposition that this article puts forward-tertiarization does not benefit female employment uniformly, but needs to be underpinned by specific institutional arrangements and policies, for its benefits to materialize. More precisely, this article proposes that those Eastern European countries which have not invested in educational expansion and reform in parallel with the expansion of their services sector, have not benefited as much from improved female employment opportunities as those that have reformed their educational systems and pursued a more knowledge-intensive services-led growth model. I test this proposition further below, as Hypothesis $1 \mathrm{~d}$.

To test Hypothesis 1c, which proposes that industrial upgrading and tertiarization have different effects on the overall levels of female labor force participation, I estimate another PCSE OLS model with fixed effects, which controls for GDP per capita.

\section{Table 1}

Female labor force participation, economic complexity and value added of services in GDP: PCSE OLS econometric estimates with fixed effects, all countries 1997-2015

\begin{tabular}{lll}
\hline & $\mathbf{( 1 )}$ & $\mathbf{( 2 )}$ \\
\hline Services, VA & 0.303 & 0.222 \\
& $(3.01)^{* * *}$ & $(2.30)^{* *}$ \\
Economic & 3.279 & 1.477 \\
Complex & $(1.27)$ & $(0.59)$ \\
Economic & 0.107 & -0.288
\end{tabular}




\begin{tabular}{|c|c|c|}
\hline complex ${ }^{2}$ & $(0.10)$ & $(0.28)$ \\
\hline GDP pc & & $\begin{array}{l}0.278 \\
(3.22)^{* * *}\end{array}$ \\
\hline HR & $\begin{array}{l}-4.462 \\
(5.27)^{* * *}\end{array}$ & $\begin{array}{l}-5.417 \\
(6.32)^{* * *}\end{array}$ \\
\hline CZ & $\begin{array}{l}-0.356 \\
(0.15)\end{array}$ & $\begin{array}{l}-0.947 \\
(0.41)\end{array}$ \\
\hline EE & $\begin{array}{l}6.447 \\
(10.08)^{* * *}\end{array}$ & $\begin{array}{l}5.097 \\
(6.69)^{* * *}\end{array}$ \\
\hline HU & $\begin{array}{l}-8.701 \\
(5.42)^{* * *}\end{array}$ & $\begin{array}{l}-8.304 \\
(5.59)^{* * *}\end{array}$ \\
\hline LV & $\begin{array}{l}4.331 \\
(5.41)^{* * *}\end{array}$ & $\begin{array}{l}3.816 \\
(5.05)^{* * *}\end{array}$ \\
\hline LT & $\begin{array}{l}6.581 \\
(9.82)^{* * *}\end{array}$ & $\begin{array}{l}5.513 \\
(7.12)^{* * *}\end{array}$ \\
\hline MK & $\begin{array}{l}-7.363 \\
(4.07)^{* * *}\end{array}$ & $\begin{array}{l}-8.266 \\
(4.96)^{* * *}\end{array}$ \\
\hline PL & $\begin{array}{l}-3.481 \\
(2.96)^{* * *}\end{array}$ & $\begin{array}{l}-3.559 \\
(3.10)^{* * *}\end{array}$ \\
\hline RO & $\begin{array}{l}-0.754 \\
(0.47)\end{array}$ & $\begin{array}{l}-1.331 \\
(0.87)\end{array}$ \\
\hline SK & $\begin{array}{l}-0.410 \\
(0.21)\end{array}$ & $\begin{array}{l}-0.601 \\
(0.32)\end{array}$ \\
\hline SI & $\begin{array}{l}1.471 \\
(0.77)\end{array}$ & $\begin{array}{l}-0.218 \\
(0.11)\end{array}$ \\
\hline _cons & $\begin{array}{l}39.391 \\
(6.38)^{* * *}\end{array}$ & $\begin{array}{l}43.857 \\
(7.46)^{* * *}\end{array}$ \\
\hline$R^{2}$ & 0.86 & 0.87 \\
\hline$N$ & 195 & 195 \\
\hline
\end{tabular}

Table 1 shows the results of the PCSE OLS estimates with fixed effects and confirms Hypothesis 1c. The estimate suggests a statistically significant positive relationship between tertiarization and female labor force participation, with and without GDP per capita as the control variable. This result suggests that within the countries, expansion of the service economy has had an average positive impact on the growth of female labor force participation. On the other hand, the increase in economic complexity as a trajectory of economic growth has not had a significant impact on the dependent variable, even when the GDP per capita control variable is excluded (model 1), which is in line with my theoretical expectation that industrial upgrading within a country impedes the expansion of female labor force participation, rather than decreases it.

To test Hypothesis 1d, which proposes that educational expansion amplifies the positive effect of tertiarization on female labor force participation, I estimate a model with marginal effects using the interaction term between the share of services in value added and the expansion of tertiary education. I thus estimate the marginal effect of expansion of services on female labor 
force participation at different levels of tertiary educational attainment. Since the correlation between the share of services in value added and tertiary educational attainment is 0.57 , the two variables are not fully correlated. This suggests that countries with a similar share of services in value added can be at different levels of tertiary educational attainment. Furthermore, the correlation between tertiary educational attainment and GDP per capita is only 0.24 , which indicates that the level of education across the countries is not determined by the level of economic development. ${ }^{2}$

Results of the econometric estimates using marginal effects, and controlling for GDP per capita, are shown in Figure 7 (and in Figures A-3 and A-4 in online supplementary material). I do not present the coefficients from the regressions because when an interaction term is included, the coefficients of the original variables have very little meaning, i.e. they show the estimated slope when the independent variable takes on the value 0 . Instead, I use marginal effect plots to show the estimated effects.

Figure 7 shows the effect of one percentage point increase of services in value added on female labor force participation at different levels of educational attainment. The statistically significant effect on female labor force participation is around 0.1 percentage points for each additional percentile of value added in services when tertiary educational attainment is fifteen percent of the population, while it is almost one percentage point when tertiary educational attainment is thirty percent and 1.2 when educational attainment is thirty-five percent. In other words, there is an almost ten-fold stronger impact of tertiarization on female labor force participation when the level of the tertiary educational attainment increases from fifteen to thirty percent of the population. This indicates that women benefit a lot more from the expansion of services in value added at higher levels of tertiary educational attainment. Analyses of the impact of the service expansion on the share of women in services employment, as well as their rates of employment in services, at the different levels of tertiary educational attainment, indicate very similar results, indicating that the overall variation in female labor force participation is shaped by the variation in female employment in services. 
Impact of interaction between value added of services in GDP and tertiary educational attainment on female labor force participation: estimated marginal effects 2000-2015

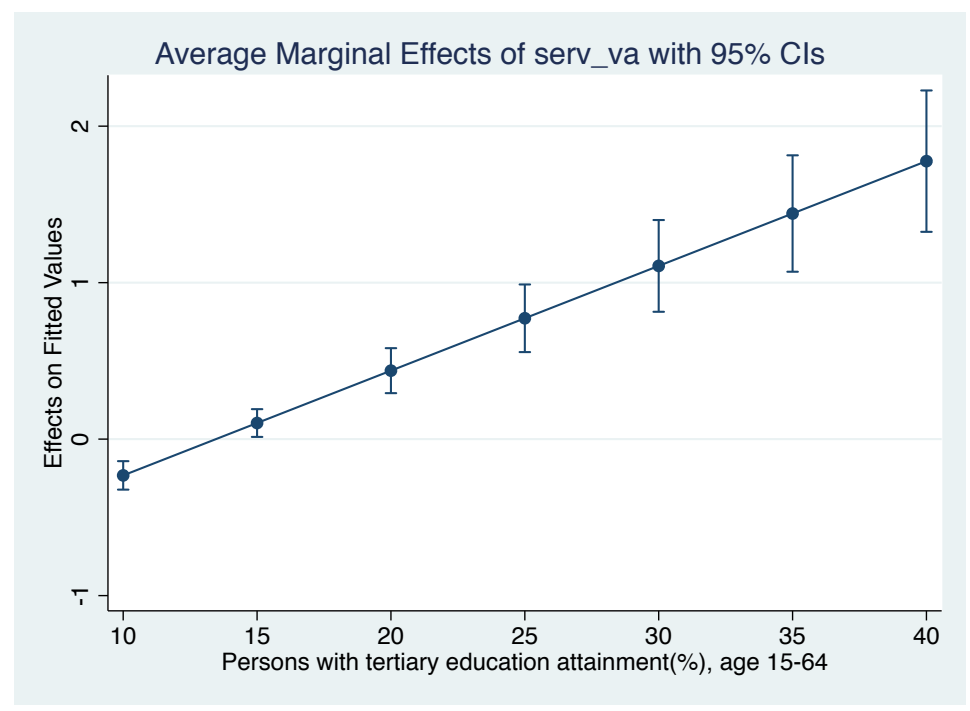

I also estimate a marginal effects model with an interaction term between expansion of services and educational expenditures to complement the above findings. Figure 8 shows the effect of growth of services in value added on female labor force participation for the different levels of educational expenditures. A statistically-significant higher effect is traced at higher levels of educational expenditures as share of GDP. The effect, in fact, doubles when educational expenditures increase from four to six percent of GDP.

\section{Figure 8}

Impact of interaction between value added of services in GDP and educational expenditures on female labor force participation: estimated marginal effects 1997-2015 


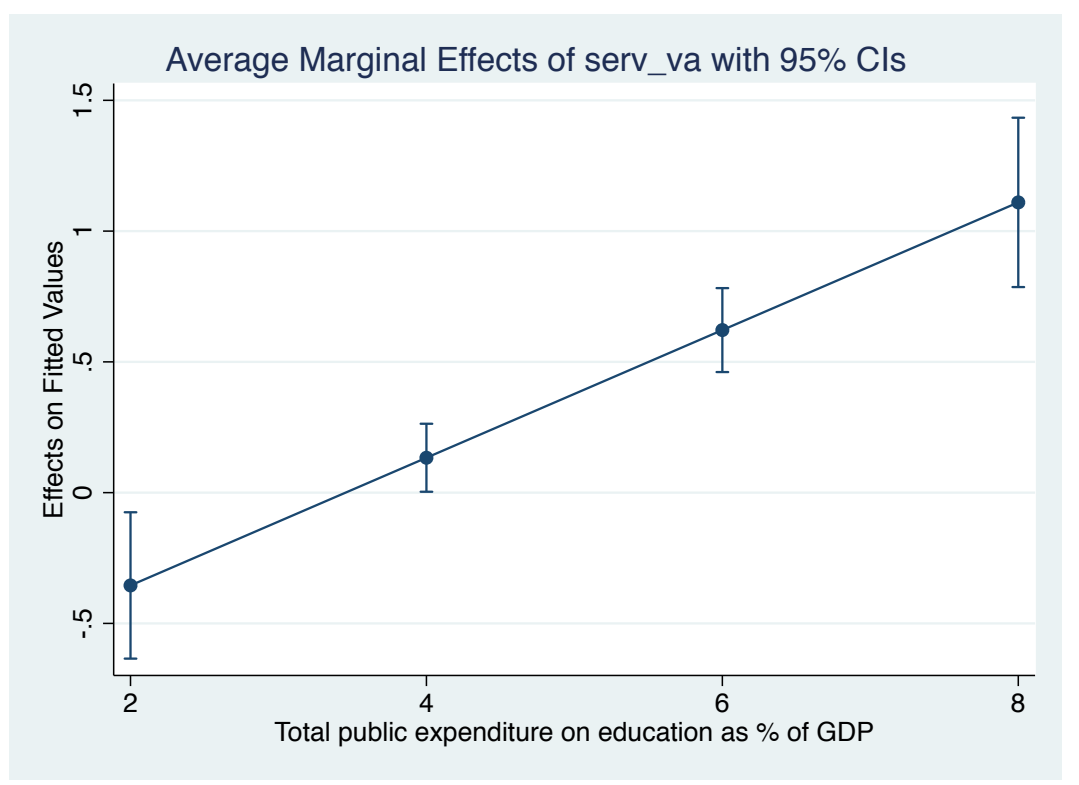

Finally, the reverse causality argument-that there may be more demand for tertiary education at higher shares of services in value added-does not apply in this case, because I have previously shown that countries with the same levels of tertiarization of their economies have varying levels of female labor force participation. Taking this into account, along with the results of the marginal effects analyses that I present above, I confirm Hypothesis $1 \mathrm{~d}$.

To test Hypothesis 1e, which proposes that the growth model based on industrial upgrading impedes public investment in educational expansion, I estimate a model where I operationalize educational expansion as the share of population with tertiary educational attainment. I also use an alternative specification of the dependent variable-expenditures on education as a share of GDP. When it comes to economic complexity as a proxy for industrial upgrading, I include the squared form of ECI. This is because I want to check for the possibility of a U-shaped relationship between economic complexity and educational expansion, since countries at higher levels of economic complexity may at some point accumulate enough resources to overcome their budgetary constraints and start investing in educational expansion. I control for GDP per capita with the caveat that, due to possible multicollinearity between ECI and GDP per capita, this control may be reducing the effect of ECI on educational expansion. Therefore, I show the results with and without GDP per capita. The other variables that might affect this relationship are fiscal constraints, and institutional and political constraints to reform 
the educational system. All of them will be covered in the fixed effects estimates, because this estimation technique controls for time invariant country level effects. ${ }^{3}$ Finally, reverse causality is not a concern, as it is difficult to theoretically posit why more tertiary educational expansion would impede industrial upgrading.

Results of the econometric estimates of the impact of economic complexity on the share of population with tertiary education are shown in Figure 9. Countries with the highest tertiary educational attainment have lower ECI (detailed in Table A-6 in online supplementary material). Therefore, there appears to be a trade-off between those countries which have higher levels of educational attainment vs those with higher levels of economic complexity. This finding supports Hypothesis 1e.

The countries with higher educational attainment and lower economic complexity are, above all, Estonia and Lithuania, two of the Baltic countries. While these countries also had the highest levels of tertiary educational attainment in 1997, the first year of data that is available to this analysis, Terama et al. (2014) shows that enrolment in tertiary education in Estonia increased by 168 percent between 1994/95 and 2005/2006, which constituted the highest growth rate in the OECD during that period (116). There was therefore a clear mandate to expand educational attainment from the earliest stages of transition. This further supports the proposition that educational expansion can amplify the positive impact of tertiarization on female employment, rather than the other way around.

\section{Figure 9}

Predicted values: tertiary educational attainment, in \% 


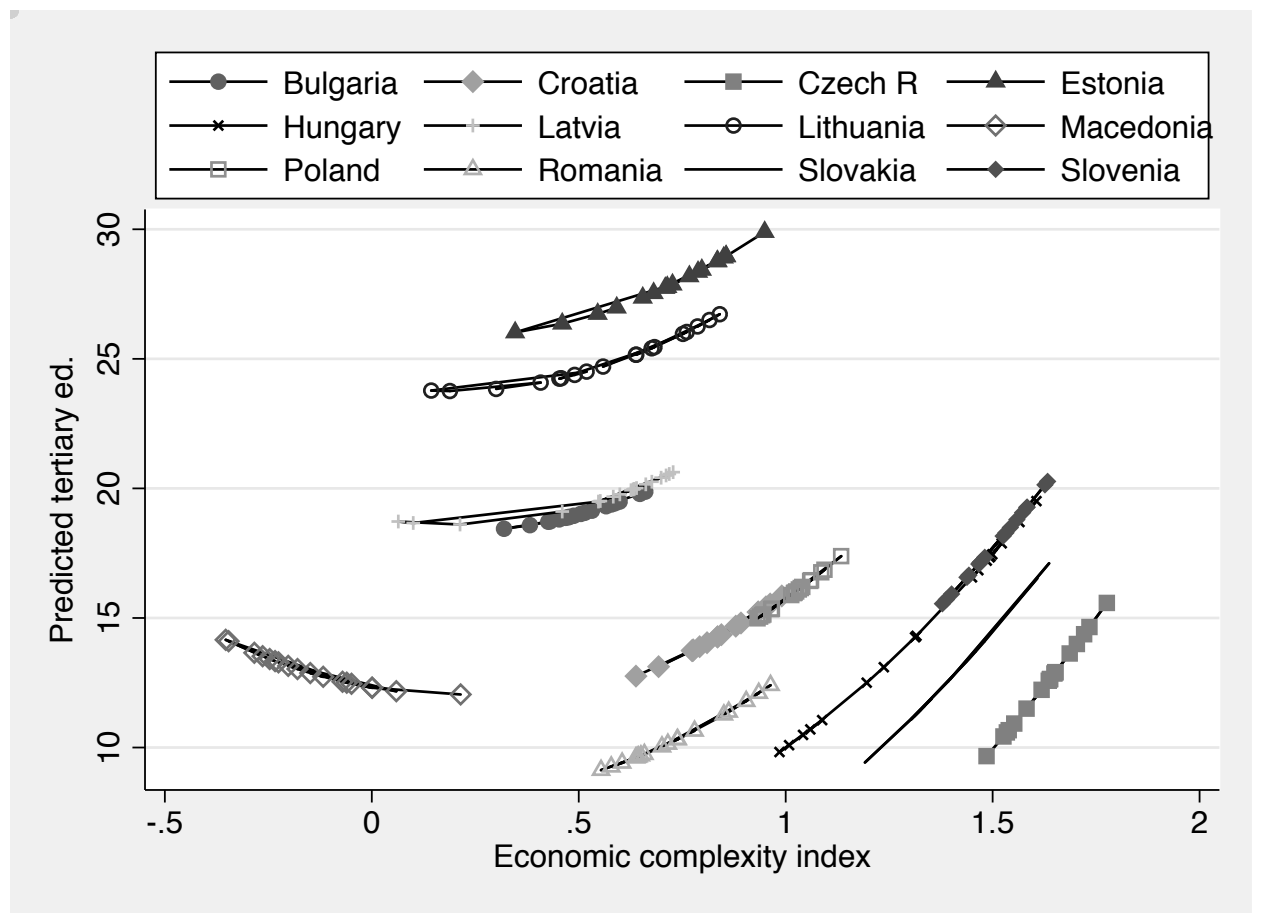

Figure 9 also shows a clear upward sloping relationship between economic complexity and tertiary educational attainment within the countries, which may appear at odds with Hypothesis 1e at first glance. Nevertheless, while educational attainment has been expanding across the countries, the fact that it has been at lower levels in Visegrad than in the Baltic indicates that this expansion of education has not yet reached a level at which it may start to substantially amplify the impact of tertiarization on female labor force participation. An alternative interpretation that would require further research is that the type of educational expansion taking place in the countries that have followed the path of industrial upgrading is more generally not conducive to employment in the service economy. Either way, this finding does not reject Hypothesis 1e. Instead, it opens new questions that should be followed up in future research projects. For example, following Ansell and Gingrich (2013), who argue that selective private higher education systems may restrain the move from manufacturing to services employment, it may be that the recent surge in privately provided tertiary education in Visegrad, which was discussed in literature review, would not have had as significant impact on female labor force participation as the state-led approach to educational expansion that we have seen in the Baltic. 
In other words, it may be the case that industrial upgrading impedes government-led educational expansion but not the privately-led one.

Estimates on the effect of industrial upgrading on educational expenditures as a share of GDP (see Table A-7 and Figure A-6 in online supplementary material), also suggest a significant negative association between industrial upgrading and educational expenditures across the countries, and therefore support Hypothesis 1e. On the other hand, the fixed effects estimates indicate a U-shaped relationship between the two variables, although the countries at the lower levels of economic complexity are predominately characterized by higher levels of educational expenditures throughout the period of observation. The U-shaped relationship between economic complexity and educational expenditures, however, may speak in favor of the mechanism that I suggest above-that emerging economies at certain stages of industrial upgrading may overcome the initial budgetary constraint and start investing more resources in educational expansion.

\section{CONCLUSIONS}

Eastern European countries had some of the highest levels of female economic activity in the world during socialism. As female labor force participation continued to increase in most of the world during the past thirty years, the trend reversed in Eastern Europe with the onset of transition. For some countries, this reversal was a temporary phenomenon, which occurred due to the negative shock of transition, while for others, low female labor force participation has become a more permanent feature of their economies.

This article explains such post-socialist cross-country divergence by showing that Eastern European countries' capitalist growth models, i.e. economic restructuring trajectories and government policies that have underpinned them, have been important determinants of female labor force participation since the early 1990s. While supply side policies, which stimulate female entry into the labor force, such as family reconciliation and childcare, may be important drivers of female work, this article draws scholarly attention to the demand for female labor and shows 
us that women work when jobs are available to them. This conclusion expands our understanding of what drives female labor force participation, which is a notoriously complex socio-economic phenomenon.

The article dovetails political economy, social policy and development economics literature into a common interdisciplinary framework, and spells out a non-linear causal mechanism between two stylized post-socialist growth models and female labor, which it refers to as the theory of reactive structuration of female labor. The theory that the article puts forward suggests that specific economic, educational and welfare restructuring reforms, and their interactions, have impacted female economic opportunities, and have led to substantial female exit from the labor market in some countries, while not in others. The theory is then empirically tested and confirmed through statistical analysis on twelve Eastern European countries during the period 1997-2015. The non-linear and multi-variate character of the causal mechanism that this article proposes and tests empirically is more comprehensive than much of the literature on the subject, which focuses on the impact of isolated individual factors on female economic activation.

Finally, the findings that this article presents suggest that the dynamics of capitalist transformation and the associated changes in economic incentives can affect gender attitudes in an economy. This further implies that cultural beliefs about women's work and economic incentives can co-evolve, as well as co-regress. Such insights can serve to expand the debate on re-traditionalization of gender relations that have been observed in some Eastern European labor markets following the collapse of socialism.

\section{NOTES}

\footnotetext{
${ }^{1}$ Specific skills are acquired through on-the-job training (firm-specific) or through apprenticeship and vocational schools (industry-specific). They are valuable to the employer / industry which carried out the training but not to other employers / sectors. General skills, gained through formal education from high schools and colleges, are recognized by all employers and carry a value that is independent of the type of firm or industry.
} 


\footnotetext{
${ }^{2}$ Correlation between the share of services in value added and GDP per capita is only 0.21 , which indicates that the extent of tertiarization of the economy among the countries is not determined by the level of their economic development.

${ }^{3}$ Fiscal constraints are not necessarily time invariant, but they have been persistent in many Eastern European countries throughout the 2000s. Therefore, for the purpose of this analysis, I consider them time invariant.
}

\section{REFERENCES}

Amable, Bruno. 2003. The Diversity of Modern Capitalism. Oxford; New York: Oxford University Press.

Ansell, Ben, and Jane Gingrich. 2013. A Tale of Two Trilemmas: Varieties of Higher Education and the Service Economy. In The Political Economy of the Service Transition, edited by Anne Wren. Oxford: Oxford University Press.

Appel, Hilary. 2011. Tax Politics in Eastern Europe. Globalization, Regional Integration, and the Democratic Compromise. Ann Arbor: University of Michigan Press.

Avlijaš, Sonja, Nevena Ivanović, Marko Vladisavljević, and Sunčica Vujić, eds. 2013. The Gender Pay Gap in the Western Balkan Countries: Evidence from Serbia, Montenegro and Macedonia. Belgrade: FREN - Foundation for the Advancement of Economics.

Avlijaš, S. 2019. Beyond neoliberalism? Revisiting the welfare state in the Baltic. Europe-Asia Studies, In press.

Avlijas, Sonja, Anke Hassel, and Bruno Palier. Forthcoming. Growth Strategies and Welfare Reforms in practice. In Growth and Welfare reforms in global capitalism: How growth regimes evolve, edited by Anke Hassel and Bruno Palier. Edited volume accepted for publication by Oxford University Press.

Baccaro, Lucio, and Jonas Pontusson. 2016. Rethinking Comparative Political Economy. The Growth Model Perspective. Politics \& Society 44 (2): 175-207.

Beck, Nathaniel, and Jonathan N. Katz. 1995. What to do (and Not to Do) with Time-Series Cross- 
Section Data. American Political Science Review, 89 (03): 634-647.

Bettio, Francesca, and Alina Verashchagina. 2009. Gender segregation in the labour market: Root causes, implications and policy responses in the EU. EU Expert Group on Gender and Employment (EGGE). Luxemburg: European Commission.

Bohle, Dorothee, and Béla Greskovits. 2006. “Capitalism without Compromise: Strong Business and Weak Labor in Eastern Europe's New Transnational Industries." Studies in Comparative International Development 41 (1): 3-25.

Bohle, Dorothee, and Béla Greskovits. 2012. Capitalist Diversity on Europe's Periphery. Ithaca: Cornell University Press.

Castelló-Climent, Amparo, and Ana Hidalgo-Cabrillana. 2012. The Role of Educational Quality and Quantity in the Process of Economic Development. Economics of Education Review 31 (4): 391409.

Chase, Robert S. 1995. Women's Labor Force Participation during and after Communism: A Study of the Czech Republic and Slovakia. Yale Economic Growth Centre Discussion Paper 768. Accessed at: http://aida.wss.yale.edu/growth_pdf/cdp768.pdf.

Elson, Diane, and Ruth Pearson. 1981. Nimble Fingers Make Cheap Workers': An Analysis of Women’s Employment in Third World Export Manufacturing. Feminist Review 7: 87-107.

Estevez-Abe, Margarita. 2005. Gender Bias in Skills and Social Policies: The Varieties of Capitalism Perspective on Sex Segregation. Social Politics: International Studies in Gender, State \& Society 12 (2): 180-215.

- _ 2006. Gendering the Varieties of Capitalism. A Study of Occupational Segregation by Sex in Advanced Industrial Societies. World Politics 59 (1): 142-175.

Feldmann, Magnus. 2006. Emerging Varieties of Capitalism in Transition Countries: Industrial Relations and Wage Bargaining in Estonia and Slovenia. Comparative Political Studies 39 (7): 829-54. 
Gaddis, Isis, and Stephan Klasen. 2014. Economic Development, Structural Change, and Women's Labor Force Participation: A Reexamination of the Feminization U Hypothesis. Journal of Population Economics 27 (3): 639-81.

Hall, Peter A. 2006. Systematic Process Analysis: When and How to Use It. European Management Review 3 (1): 24-31.

Hall, Peter A., and David Soskice, eds. 2001. Varieties of Capitalism: The Institutional Foundations of Comparative Advantage. Oxford, New York: Oxford University Press.

Hassel, Anke, and Bruno Palier. Forthcoming. Growth and Welfare in Global Capitalism. In Growth and Welfare reforms in global capitalism: How growth regimes evolve, edited by Anke Hassel and Bruno Palier. Edited volume accepted for publication by Oxford University Press.

Hausmann, Ricardo, Cesar A Hidalgo, Sebastián Bustos, Michele Coscia, Sarah Chung, Juan Jimenez, Alexander Simões, and Muhammed A Yıldırım. 2011. The Atlas of Economic Complexity: Mapping Paths to Prosperity. Cambridge, MA: Center for International Development, Harvard University: Harvard Kennedy School; Macro Connections, MIT: Massachusetts Institute of Technology.

Huber, Evelyne, and John D. Stephens. 2000. Partisan Governance, Women's Employment, and the Social Democratic Service State. American Sociological Review 65 (3): 323.

Humphries, Jane, and Carmen Sarasúa. 2012. Off the Record: Reconstructing Women's Labor Force Participation in the European Past. Feminist Economics 18 (4): 39-67.

Iversen, Torben, Frances Rosenbluth, and David Soskice. 2005. Divorce and the Gender Division of Labor in Comparative Perspective. Social Politics: International Studies in Gender, State \& Society $12(2): 216-42$.

Lobodzinska, Barbara, ed. 1995. Family, Women, and Employment in Central-Eastern Europe. Westport: Praeger Publishers.

Martinaitis, Žilvinas. 2010. The Political Economy of Skills Formation: Explaining Differences in Central and Eastern Europe. PhD Thesis, Institute of International Relations and Political Science, Vilnius 
University.

McCall, Leslie, and Ann Shola Orloff. 2005. Introduction to Special Issue of Social Politics: 'Gender, Class, and Capitalism. Social Politics: International Studies in Gender, State \& Society 12 (2): 15969.

Morel, Nathalie, Joakim Palme, and Bruno Palier. 2012. Towards a Social Investment Welfare State?: Ideas, Policies and Challenges. Bristol: Policy Press.

Nelson, Moira, and John D. Stephens. 2012. Do Social Investment Policies Produce More and Better Jobs? In Towards A Social Investment Welfare State? Ideas, Policies and Challenges, edited by Nathalie Morel, Bruno Palier, and Joakim Palme, 205-34. Bristol: Policy Press.

_-_ 2013. The Service Transition and Women's Employment. In The Political Economy of the Service Transition, edited by Anne Wren. Oxford: Oxford University Press.

Nölke, Andreas, and Arjan Vliegenthart. 2009. Enlarging the Varieties of Capitalism: The Emergence of Dependent Market Economies in East Central Europe. World Politics 61 (4): 670.

OECD. 2016. PISA 2015 Results (Volume I): Excellence and Equity in Education. Paris: OECD Publishing. Runnel, Pille, Pille Pruulmann-Vengerfeldt, and Kristina Reinsalu. 2009. The Estonian Tiger Leap from Post-Communism to the Information Society: From Policy to Practice. Journal of Baltic Studies 40 (1): 29-51.

Sainsbury, Diane, 1999. Gender and Welfare State Regimes. Oxford, New York: Oxford University Press.

Shalev, Michael. 2007. Limits and Alternatives to Multiple Regression in Comparative Research. In Capitalisms Compared (Comparative Social Research, Volume 24), ed. Lars Mjøset and Tommy H. Clausen, 261-308. Bingley: Emerald Group Publishing Limited.

Tarlea, Silvana. 2015. Dependency and Development in Central and Eastern Europe's New Capitalist Systems. DPhil Thesis, Nuffield College, University of Oxford.

Tejani, Sheba, and William Milberg. 2016. Global Defeminization? Industrial Upgrading and 
Manufacturing Employment in Developing Countries. Feminist Economics 22 (2), 24-54.

Terama, Emma, Anu Kõu, and K. C. Samir. 2014. Early Transition Trends and Differences of Higher Education Attainment in the Former Soviet Union, Central and Eastern European Countries. Finnish Yearbook of Population Research 49: 105.

Thelen, Kathleen. 2012. Varieties of Capitalism: Trajectories of Liberalization and the New Politics of Social Solidarity. Annual Review of Political Science 15 (1): 137-59.

-_- 2014. Varieties of Liberalization and the New Politics of Social Solidarity. Cambridge; New York: Cambridge University Press.

Vanhuysse, Pieter. 2006. Divide and Pacify: Strategic Social Policies and Political Protests in PostCommunist Democracies. Budapest; New York: Central European University Press.

World Bank. 2011. World Development Report 2012: Gender Equality and Development. Washington D.C.: The World Bank.

Wren, Anne, Mate Fodor, and Sotiria Theodoropoulou. 2013. The Trilemma Revisited: Institutions, Inequality, and Employment Creation in an Era of ICT-Intensive Service Expansion. In The Political Economy of the Service Transition, edited by Anne Wren, 1-99. Oxford: Oxford University Press.

\section{ONLINE SUPPLEMENTARY MATERIAL}

Table A-1

Economic complexity and \% of women in total manufacturing employment: PCSE OLS econometric estimates with fixed effects, all countries 1997-2015

\begin{tabular}{|c|c|c|c|c|}
\hline & (1) & (2) & (3) & (4) \\
\hline $\begin{array}{l}\text { Economic } \\
\text { complex }\end{array}$ & $\begin{array}{l}-5.884 \\
(3.26)^{* * *}\end{array}$ & $\begin{array}{l}1.324 \\
(0.93)\end{array}$ & $\begin{array}{l}2.381 \\
(1.01)\end{array}$ & $\begin{array}{l}7.358 \\
(3.21)^{* * * *}\end{array}$ \\
\hline $\begin{array}{l}\text { Economic } \\
\text { complex }^{2}\end{array}$ & & & $\begin{array}{l}-5.150 \\
(5.11)^{* * *}\end{array}$ & $\begin{array}{l}-3.988 \\
(4.58)^{* * * *}\end{array}$ \\
\hline GDP pc & & $\begin{array}{l}-0.691 \\
(4.58)^{* * * *}\end{array}$ & & $\begin{array}{l}-0.655 \\
(4.42)^{* * * *}\end{array}$ \\
\hline
\end{tabular}




\begin{tabular}{|c|c|c|c|c|}
\hline HR & $\begin{array}{l}-10.957 \\
(15.51)^{* * *}\end{array}$ & $\begin{array}{l}-8.672 \\
(8.33)^{* * *}\end{array}$ & $\begin{array}{l}-11.440 \\
(17.10)^{* * *}\end{array}$ & $\begin{array}{l}-9.163 \\
(8.95)^{* * *}\end{array}$ \\
\hline CZ & $\begin{array}{l}-6.148 \\
(2.86)^{* * *}\end{array}$ & $\begin{array}{l}-6.358 \\
(3.26)^{* * *}\end{array}$ & $\begin{array}{l}-3.135 \\
(1.48)\end{array}$ & $\begin{array}{l}-4.014 \\
(2.29)^{* *}\end{array}$ \\
\hline EE & $\begin{array}{l}-3.893 \\
(4.77)^{* * *}\end{array}$ & $\begin{array}{l}-0.284 \\
(0.22)\end{array}$ & $\begin{array}{l}-4.280 \\
(5.40)^{* * *}\end{array}$ & $\begin{array}{l}-0.768 \\
(0.61)\end{array}$ \\
\hline HU & $\begin{array}{l}-5.664 \\
(3.63)^{* * *}\end{array}$ & $\begin{array}{l}-7.427 \\
(5.78)^{* * *}\end{array}$ & $\begin{array}{l}-4.582 \\
(3.02)^{* * *}\end{array}$ & $\begin{array}{l}-6.499 \\
(5.65)^{* * *}\end{array}$ \\
\hline LV & $\begin{array}{l}-6.367 \\
(14.31)^{* * *}\end{array}$ & $\begin{array}{l}-3.727 \\
(4.65)^{* * *}\end{array}$ & $\begin{array}{l}-6.364 \\
(14.38)^{* * *}\end{array}$ & $\begin{array}{l}-3.860 \\
(4.95)^{* * *}\end{array}$ \\
\hline LT & $\begin{array}{l}-1.182 \\
(2.46)^{* *}\end{array}$ & $\begin{array}{l}1.402 \\
(1.86)^{*}\end{array}$ & $\begin{array}{l}-1.255 \\
(2.52)^{* *}\end{array}$ & $\begin{array}{l}1.214 \\
(1.62)\end{array}$ \\
\hline MK & $\begin{array}{l}-6.507 \\
(4.43)^{* * *}\end{array}$ & $\begin{array}{l}-2.642 \\
(2.55)^{* *}\end{array}$ & $\begin{array}{l}-1.859 \\
(1.20)\end{array}$ & $\begin{array}{l}0.760 \\
(0.50)\end{array}$ \\
\hline PL & $\begin{array}{l}-12.688 \\
(12.66)^{* * *}\end{array}$ & $\begin{array}{l}-12.999 \\
(14.23)^{* *}\end{array}$ & $\begin{array}{l}-12.960 \\
(13.54)^{* * *}\end{array}$ & $\begin{array}{l}-13.194 \\
(14.82)^{* * *}\end{array}$ \\
\hline RO & $\begin{array}{l}-3.256 \\
(5.10)^{* * *}\end{array}$ & $\begin{array}{l}-4.367 \\
(8.08)^{* * *}\end{array}$ & $\begin{array}{l}-3.691 \\
(5.96)^{* * *}\end{array}$ & $\begin{array}{l}-4.647 \\
(8.56)^{* * *}\end{array}$ \\
\hline SK & $\begin{array}{l}-6.890 \\
(3.87)^{* * *}\end{array}$ & $\begin{array}{l}-7.843 \\
(5.32)^{* * *}\end{array}$ & $\begin{array}{l}-5.597 \\
(3.29)^{* * *}\end{array}$ & $\begin{array}{l}-6.793 \\
(5.08)^{* * *}\end{array}$ \\
\hline SI & $\begin{array}{l}-7.269 \\
(3.54)^{* * *}\end{array}$ & $\begin{array}{l}-4.017 \\
(1.72)^{*}\end{array}$ & $\begin{array}{l}-5.233 \\
(2.61)^{* * *}\end{array}$ & $\begin{array}{l}-2.606 \\
(1.19)\end{array}$ \\
\hline _cons & $\begin{array}{l}52.693 \\
(58.39)^{* * *}\end{array}$ & $\begin{array}{l}53.347 \\
(58.10)^{* *}\end{array}$ & $\begin{array}{l}49.914 \\
(49.67)^{* * *}\end{array}$ & $\begin{array}{l}51.162 \\
(46.18)^{* * *}\end{array}$ \\
\hline$R^{2}$ & 0.85 & 0.90 & 0.86 & 0.90 \\
\hline$N$ & 191 & 191 & 191 & 191 \\
\hline
\end{tabular}

As an additional measure of defeminization of manufacturing employment, I use female employment in manufacturing as a share of the total female working age population. This specification of the model also indicates a slightly positive relationship between the two variables at the lower levels of economic complexity, following which we see a sharp fall in female employment in manufacturing as economic complexity increases, both within and across the analyzed countries (see Table A-2 and Figure A-1 below).

Table A-2

Economic complexity and rate of female employment in manufacturing: PCSE OLS econometric estimates with fixed effects, all countries 1997-2015

(1) (2) (3) (4)




\begin{tabular}{|c|c|c|c|c|}
\hline $\begin{array}{l}\text { Economic } \\
\text { complex }\end{array}$ & $\begin{array}{l}-3.285 \\
(3.04)^{* * *}\end{array}$ & $\begin{array}{l}-0.016 \\
(0.02)\end{array}$ & $\begin{array}{l}0.152 \\
(0.11)\end{array}$ & $\begin{array}{l}2.422 \\
(1.71)^{*}\end{array}$ \\
\hline $\begin{array}{l}\text { Economic } \\
\text { complex }^{2}\end{array}$ & & & $\begin{array}{l}-2.142 \\
(3.87)^{* * *}\end{array}$ & $\begin{array}{l}-1.612 \\
(2.63)^{* * *}\end{array}$ \\
\hline GDP pc & & $\begin{array}{l}-0.313 \\
(2.84)^{* * *}\end{array}$ & & $\begin{array}{l}-0.299 \\
(2.73)^{* * *}\end{array}$ \\
\hline HR & $\begin{array}{l}-4.047 \\
(8.52)^{* * *}\end{array}$ & $\begin{array}{l}-3.011 \\
(3.92)^{* * *}\end{array}$ & $\begin{array}{l}-4.248 \\
(9.12)^{* * *}\end{array}$ & $\begin{array}{l}-3.210 \\
(4.16)^{* * *}\end{array}$ \\
\hline CZ & $\begin{array}{l}4.424 \\
(3.31)^{* * *}\end{array}$ & $\begin{array}{l}4.329 \\
(3.19)^{* * *}\end{array}$ & $\begin{array}{l}5.677 \\
(4.36)^{* * *}\end{array}$ & $\begin{array}{l}5.276 \\
(4.18)^{* * *}\end{array}$ \\
\hline EE & $\begin{array}{l}-0.116 \\
(0.29)\end{array}$ & $\begin{array}{l}1.520 \\
(1.75)^{*}\end{array}$ & $\begin{array}{l}-0.277 \\
(0.71)\end{array}$ & $\begin{array}{l}1.325 \\
(1.52)\end{array}$ \\
\hline HU & $\begin{array}{l}-0.313 \\
(0.30)\end{array}$ & $\begin{array}{l}-1.112 \\
(1.21)\end{array}$ & $\begin{array}{l}0.137 \\
(0.14)\end{array}$ & $\begin{array}{l}-0.737 \\
(0.85)\end{array}$ \\
\hline $\mathbf{L V}$ & $\begin{array}{l}-4.486 \\
(17.50)^{* * *}\end{array}$ & $\begin{array}{l}-3.289 \\
(5.92)^{* * *}\end{array}$ & $\begin{array}{l}-4.485 \\
(17.36)^{* *}\end{array}$ & $\begin{array}{l}-3.342 \\
(6.07)^{* * *}\end{array}$ \\
\hline LT & $\begin{array}{l}-2.443 \\
(7.98)^{* * *}\end{array}$ & $\begin{array}{l}-1.271 \\
(2.15)^{* *}\end{array}$ & $\begin{array}{l}-2.473 \\
(8.07)^{* * *}\end{array}$ & $\begin{array}{l}-1.347 \\
(2.29)^{* *}\end{array}$ \\
\hline MK & $\begin{array}{l}-6.540 \\
(7.96)^{* * *}\end{array}$ & $\begin{array}{l}-4.788 \\
(6.98)^{* * *}\end{array}$ & $\begin{array}{l}-4.607 \\
(4.83)^{* * *}\end{array}$ & $\begin{array}{l}-3.413 \\
(3.59)^{* * *}\end{array}$ \\
\hline PL & $\begin{array}{l}-3.697 \\
(5.45)^{* * *}\end{array}$ & $\begin{array}{l}-3.838 \\
(5.32)^{* * *}\end{array}$ & $\begin{array}{l}-3.810 \\
(5.74)^{* * *}\end{array}$ & $\begin{array}{l}-3.917 \\
(5.49)^{* * *}\end{array}$ \\
\hline RO & $\begin{array}{l}-0.210 \\
(0.49)\end{array}$ & $\begin{array}{l}-0.714 \\
(1.91)^{*}\end{array}$ & $\begin{array}{l}-0.391 \\
(0.93)\end{array}$ & $\begin{array}{l}-0.827 \\
(2.21)^{* *}\end{array}$ \\
\hline SK & $\begin{array}{l}1.423 \\
(1.33)\end{array}$ & $\begin{array}{l}0.991 \\
(0.99)\end{array}$ & $\begin{array}{l}1.961 \\
(1.88)^{*}\end{array}$ & $\begin{array}{l}1.416 \\
(1.49)\end{array}$ \\
\hline SI & $\begin{array}{l}4.231 \\
(3.13)^{* * *}\end{array}$ & $\begin{array}{l}5.705 \\
(3.33)^{* * *}\end{array}$ & $\begin{array}{l}5.077 \\
(3.88)^{* * *}\end{array}$ & $\begin{array}{l}6.276 \\
(3.87)^{* * *}\end{array}$ \\
\hline _cons & $\begin{array}{l}14.373 \\
(24.15)^{* * *}\end{array}$ & $\begin{array}{l}14.670 \\
(22.47)^{* * *}\end{array}$ & $\begin{array}{l}13.218 \\
(19.53)^{* * *}\end{array}$ & $\begin{array}{l}13.787 \\
(17.27)^{* * *}\end{array}$ \\
\hline$R^{2}$ & 0.77 & 0.81 & 0.78 & 0.82 \\
\hline$N$ & 191 & 191 & 191 & 191 \\
\hline
\end{tabular}

Figure A-1

Predicted values: rate of female employment in manufacturing (using least squares dummy variable estimator) 


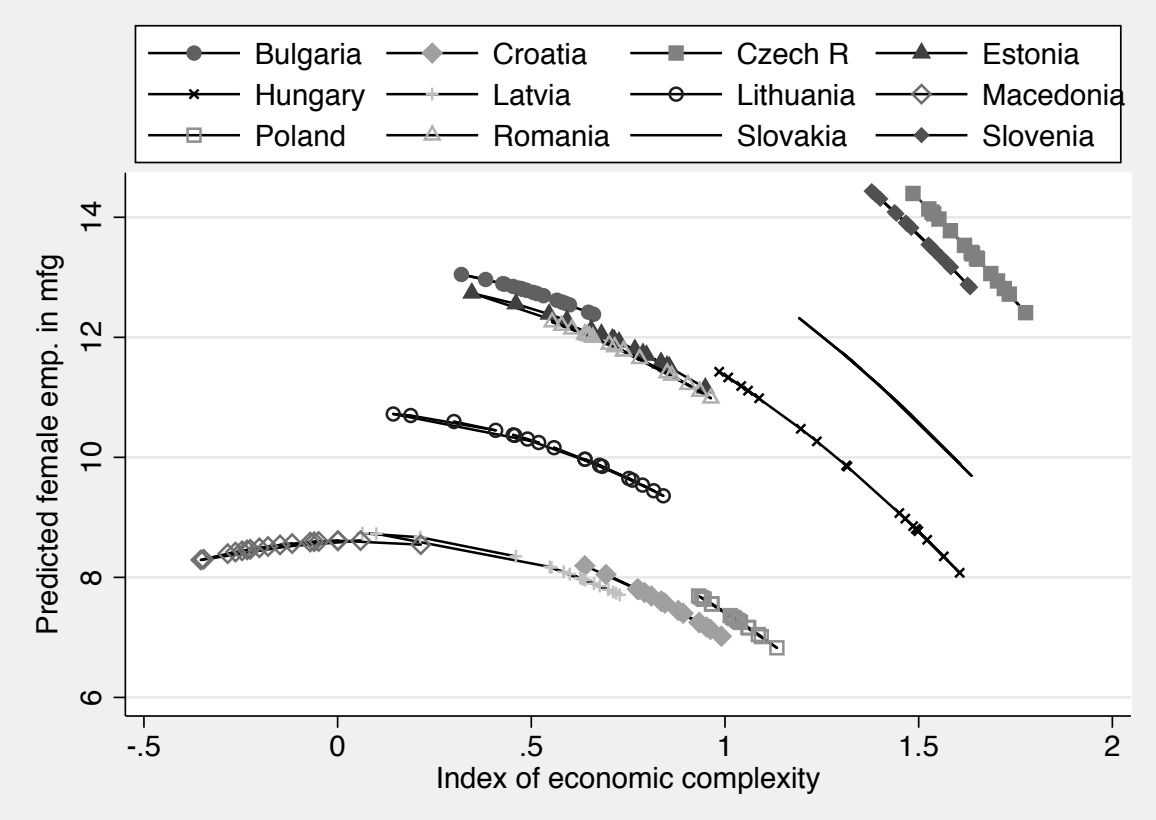

Table A-3

Share of women in services and value added of services in GDP:

PCSE OLS econometric estimates with fixed effects, all countries 1997-2015

\begin{tabular}{lll}
\hline & $(\mathbf{1})$ & $\mathbf{( 2 )}$ \\
\hline Services, & 0.124 & 0.091 \\
VA & $(5.29)^{* * *}$ & $(3.64)^{* * *}$ \\
GDP pc & & 0.068 \\
& & $(2.62)^{* * *}$ \\
HR & -0.471 & -0.872 \\
& $(1.16)$ & $(1.85)^{*}$ \\
CZ & 1.374 & 0.429 \\
& $(6.55)^{* * *}$ & $(1.02)$ \\
EE & 6.166 & 5.659 \\
& $(20.18)^{* * *}$ & $(15.65)^{* * *}$ \\
HU & 1.258 & 0.828 \\
& $(10.12)^{* * *}$ & $(4.04)^{* * *}$ \\
LV & 5.133 & 5.016 \\
& $(21.07)^{* * *}$ & $(21.61)^{* * *}$ \\
LT & 6.120 & 5.736 \\
& $(33.34)^{* * *}$ & $(23.33)^{* * *}$ \\
MK & -11.397 & -11.302 \\
& $(25.89)^{* * *}$ & $(26.84)^{* * *}$ \\
PL & 2.460 & 2.094 \\
& $(18.11)^{* * *}$ & $(10.98)^{* * *}$ \\
RO & -1.370 & -1.790 \\
& $(4.65)^{* * *}$ & $(5.56)^{* * *}$ \\
SK & 3.918 & 3.233 \\
& & \\
& & \\
& & \\
& & \\
& &
\end{tabular}




\begin{tabular}{lll} 
& $(28.77)^{* * *}$ & $(10.46)^{* * *}$ \\
SI & 1.629 & 0.557 \\
& $(17.57)^{* * *}$ & $(1.30)$ \\
& & \\
_cons & 45.919 & 47.606 \\
$\boldsymbol{R}^{2}$ & $(30.57)^{* * *}$ & $(30.70)^{* * *}$ \\
$\boldsymbol{N}$ & 0.96 & 0.96 \\
\hline \multirow{2}{*}{${ }^{*} p<0.1 ;{ }^{* *} p<0.05 ;{ }^{* * *} p<0.01$}
\end{tabular}

As an additional measure of feminization of employment in the service economy, I use female employment in services as a share of the total female working age population. This specification of the model also indicates that the higher value added of services can be significantly associated with the higher rate of female employment in services, thus further confirming Hypothesis 2 (see Table A-4 and Figure A-2 below).

\section{Table A-4}

Rates of female employment in services and value added of services in GDP: PCSE OLS econometric estimates with fixed effects, all countries 1997-2015

\begin{tabular}{lll}
\hline & $(\mathbf{1})$ & $\mathbf{( 2 )}$ \\
\hline Services, & 0.954 & 0.369 \\
VA & $(7.05)^{* * *}$ & $(5.96)^{* * *}$ \\
& & 1.220 \\
GDP pc & & $(17.63)^{* * *}$ \\
& & \\
HR & -4.819 & -12.005 \\
& $(7.63)^{* * *}$ & $(20.34)^{* * *}$ \\
CZ & 8.800 & -8.120 \\
& $(12.30)^{* * *}$ & $(6.79)^{* * *}$ \\
EE & 9.394 & 0.325 \\
& $(12.04)^{* * *}$ & $(0.42)$ \\
HU & 1.310 & -6.385 \\
& $(2.03)^{* *}$ & $(9.70)^{* * *}$ \\
LV & 3.212 & 1.125 \\
& $(2.76)^{* * *}$ & $(1.75)^{*}$ \\
LT & 8.164 & 1.296 \\
& $(12.12)^{* * *}$ & $(1.93)^{*}$ \\
MK & -16.839 & -15.133 \\
& $(17.39)^{* * *}$ & $(21.56)^{* * *}$ \\
PL & -2.271 & -8.826 \\
& $(5.01)^{* * *}$ & $(17.21)^{* * *}$ \\
RO & -1.780 & -9.287 \\
& &
\end{tabular}




\begin{tabular}{|c|c|c|}
\hline & (1.09) & $(9.66)^{* * *}$ \\
\hline SK & $\begin{array}{l}5.845 \\
(11.49)^{* * *}\end{array}$ & $\begin{array}{l}-6.408 \\
(6.32)^{* * *}\end{array}$ \\
\hline SI & $\begin{array}{l}5.395 \\
(21.38)^{* * * *}\end{array}$ & $\begin{array}{l}-13.794 \\
(11.36)^{* * *}\end{array}$ \\
\hline _cons & $\begin{array}{l}-25.074 \\
(2.90)^{* * *}\end{array}$ & $\begin{array}{l}5.115 \\
(1.29)\end{array}$ \\
\hline$R^{2}$ & 0.88 & 0.96 \\
\hline$N$ & 186 & 186 \\
\hline
\end{tabular}

Figure A-2

Predicted values: rate of female employment in services

(using least squares dummy variable estimator)

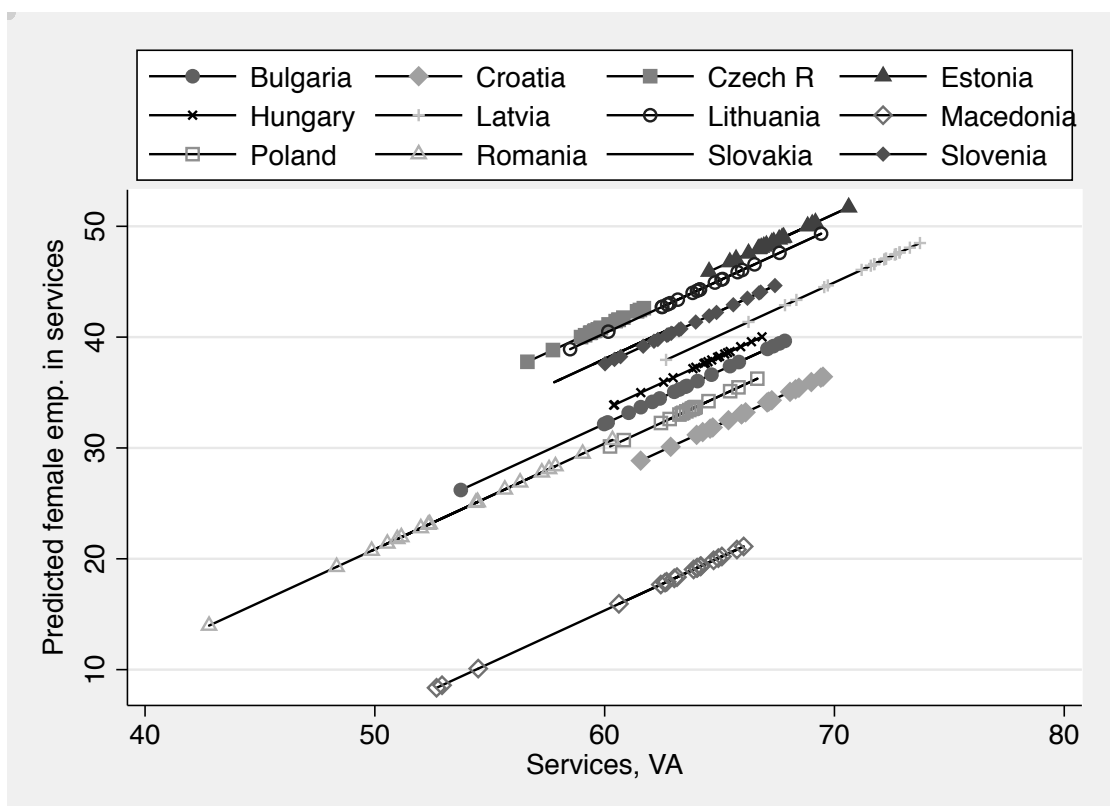

Figure A-3

Impact of interaction between value added of services in GDP and tertiary educational attainment on share of women in service employment: estimated marginal effects 2000-2015 


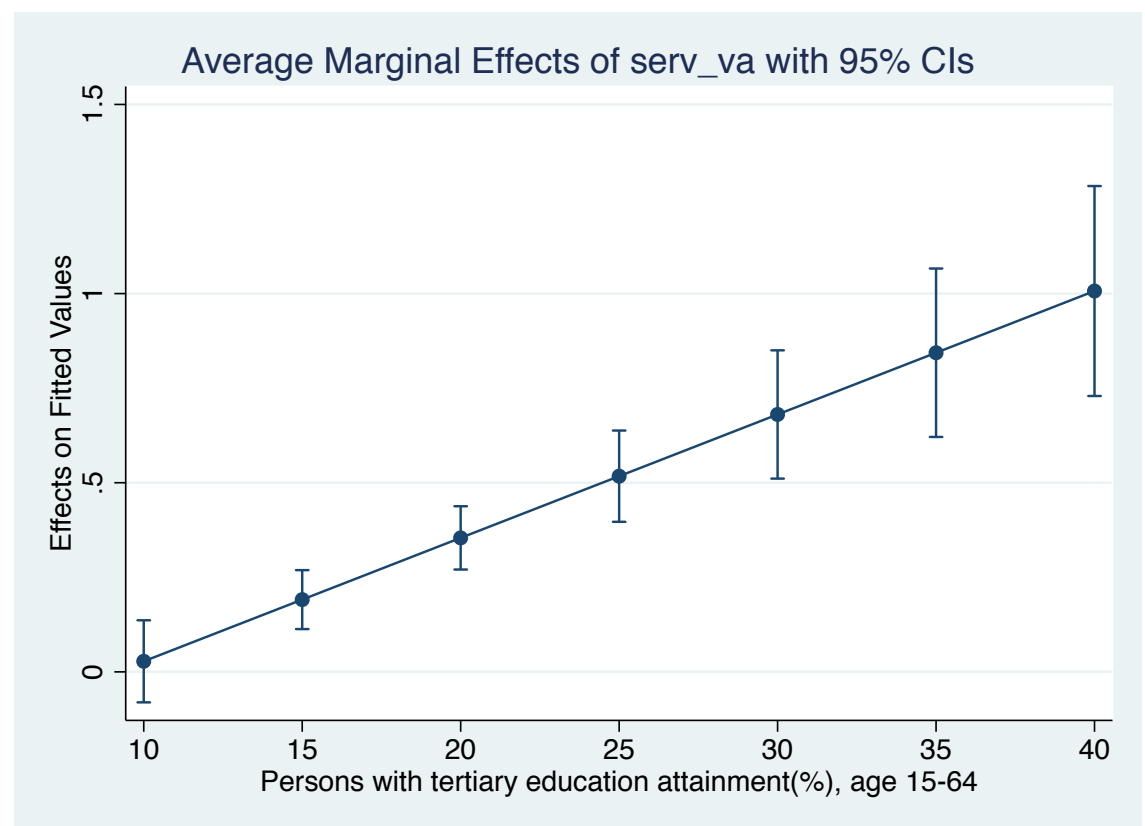

Figure A-4

Impact of interaction between value added of services in GDP and tertiary educational attainment on rate of female employment in services: estimated marginal effects 2000-2015

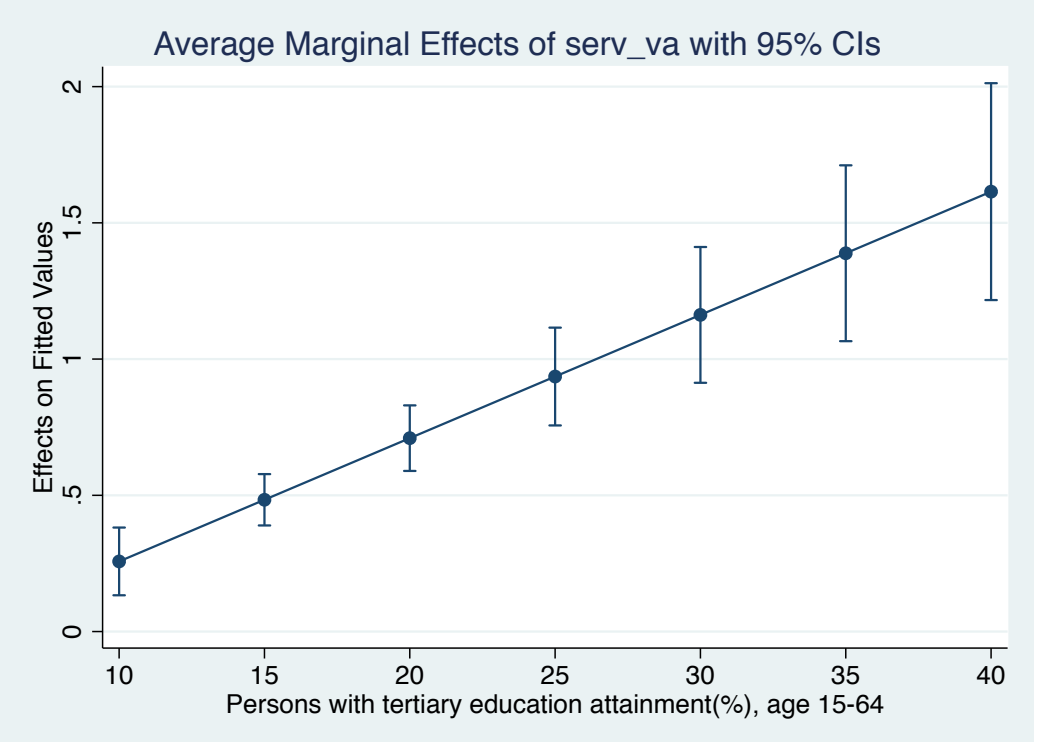

Table A-6

Tertiary educational attainment and industrial upgrading:

PCSE OLS econometric estimates with fixed effects, all countries 1997-2015 


\begin{tabular}{|c|c|c|c|c|}
\hline & (1) & (2) & (3) & (4) \\
\hline $\begin{array}{l}\text { Economic } \\
\text { complex }\end{array}$ & $\begin{array}{l}8.683 \\
(2.66)^{* * *}\end{array}$ & $\begin{array}{l}-3.869 \\
(1.82)^{*}\end{array}$ & $\begin{array}{l}-2.739 \\
(0.59)\end{array}$ & $\begin{array}{l}-12.015 \\
(3.43)^{* * *}\end{array}$ \\
\hline $\begin{array}{l}\text { Economic } \\
\text { complex }^{2}\end{array}$ & & & $\begin{array}{l}7.076 \\
(3.79)^{* * *}\end{array}$ & $\begin{array}{l}5.226 \\
(3.74)^{* * *}\end{array}$ \\
\hline GDP pc & & $\begin{array}{l}1.432 \\
(5.57)^{* * *}\end{array}$ & & $\begin{array}{l}1.399 \\
(5.56)^{* * *}\end{array}$ \\
\hline HR & $\begin{array}{l}-7.666 \\
(6.61)^{* * *}\end{array}$ & $\begin{array}{l}-13.334 \\
(7.67)^{* * *}\end{array}$ & $\begin{array}{l}-6.977 \\
(6.03)^{* * *}\end{array}$ & $\begin{array}{l}-12.693 \\
(7.47)^{* * *}\end{array}$ \\
\hline CZ & $\begin{array}{l}-16.162 \\
(4.24)^{* * *}\end{array}$ & $\begin{array}{l}-19.237 \\
(5.55)^{* * *}\end{array}$ & $\begin{array}{l}-20.472 \\
(5.50)^{* * *}\end{array}$ & $\begin{array}{l}-22.349 \\
(6.69)^{* * *}\end{array}$ \\
\hline EE & $\begin{array}{l}6.908 \\
(7.13)^{* * *}\end{array}$ & $\begin{array}{l}-1.971 \\
(0.90)\end{array}$ & $\begin{array}{l}7.524 \\
(7.76)^{* * *}\end{array}$ & $\begin{array}{l}-1.310 \\
(0.61)\end{array}$ \\
\hline HU & $\begin{array}{l}-11.128 \\
(3.79)^{* * *}\end{array}$ & $\begin{array}{l}-9.432 \\
(4.23)^{* * *}\end{array}$ & $\begin{array}{l}-12.937 \\
(4.55)^{* * *}\end{array}$ & $\begin{array}{l}-10.808 \\
(5.11)^{* * *}\end{array}$ \\
\hline LV & $\begin{array}{l}-0.053 \\
(0.07)\end{array}$ & $\begin{array}{l}-5.780 \\
(4.15)^{* * *}\end{array}$ & $\begin{array}{l}0.273 \\
(0.38)\end{array}$ & $\begin{array}{l}-5.406 \\
(3.96)^{* * *}\end{array}$ \\
\hline LT & $\begin{array}{l}5.154 \\
(9.98)^{* * *}\end{array}$ & $\begin{array}{l}-0.728 \\
(0.54)\end{array}$ & $\begin{array}{l}5.428 \\
(10.81)^{* *}\end{array}$ & $\begin{array}{l}-0.389 \\
(0.30)\end{array}$ \\
\hline MK & $\begin{array}{l}0.506 \\
(0.19)\end{array}$ & $\begin{array}{l}-6.182 \\
(4.00)^{* * *}\end{array}$ & $\begin{array}{l}-6.286 \\
(1.98)^{* *}\end{array}$ & $\begin{array}{l}-11.044 \\
(4.82)^{* * *}\end{array}$ \\
\hline PL & $\begin{array}{l}-7.613 \\
(4.01)^{* * *}\end{array}$ & $\begin{array}{l}-8.248 \\
(5.42)^{* * *}\end{array}$ & $\begin{array}{l}-7.205 \\
(3.90)^{* * *}\end{array}$ & $\begin{array}{l}-7.932 \\
(5.32)^{* * *}\end{array}$ \\
\hline RO & $\begin{array}{l}-10.738 \\
(12.28)^{* * *}\end{array}$ & $\begin{array}{l}-9.489 \\
(16.20)^{* * *}\end{array}$ & $\begin{array}{l}-10.120 \\
(11.40)^{* *} \\
*\end{array}$ & $\begin{array}{l}-9.062 \\
(14.70)^{* * *}\end{array}$ \\
\hline SK & $\begin{array}{l}-14.157 \\
(4.74)^{* * *}\end{array}$ & $\begin{array}{l}-14.972 \\
(5.95)^{* * *}\end{array}$ & $\begin{array}{l}-15.953 \\
(5.52)^{* * *}\end{array}$ & $\begin{array}{l}-16.280 \\
(6.72)^{* * *}\end{array}$ \\
\hline SI & $\begin{array}{l}-9.801 \\
(2.85)^{* * *}\end{array}$ & $\begin{array}{l}-19.959 \\
(4.78)^{* * *}\end{array}$ & $\begin{array}{l}-12.722 \\
(3.82)^{* * *}\end{array}$ & $\begin{array}{l}-21.880 \\
(5.42)^{* * *}\end{array}$ \\
\hline _cons & $\begin{array}{l}14.745 \\
(8.89)^{* * *}\end{array}$ & $\begin{array}{l}12.216 \\
(7.38)^{* * *}\end{array}$ & $\begin{array}{l}18.595 \\
(9.25)^{* * *}\end{array}$ & $\begin{array}{l}15.118 \\
(8.09)^{* * *}\end{array}$ \\
\hline$R^{2}$ & 0.73 & 0.87 & 0.75 & 0.87 \\
\hline$N$ & 172 & 172 & 172 & 172 \\
\hline
\end{tabular}

Table A-7

Educational expenditures and industrial upgrading:

PCSE OLS econometric estimates with fixed effects, all countries 1997-2015 


\begin{tabular}{|c|c|c|c|c|}
\hline & (1) & (2) & (3) & (4) \\
\hline $\begin{array}{l}\text { Economic } \\
\text { complex }\end{array}$ & $\begin{array}{l}-0.317 \\
(1.06)\end{array}$ & $\begin{array}{l}-0.439 \\
(1.39)\end{array}$ & $\begin{array}{l}-1.239 \\
(1.81)^{*}\end{array}$ & $\begin{array}{l}-1.326 \\
(2.03)^{* *}\end{array}$ \\
\hline $\begin{array}{l}\text { Economic } \\
\text { complex }^{2}\end{array}$ & & & $\begin{array}{l}0.563 \\
(1.72)^{*}\end{array}$ & $\begin{array}{l}0.556 \\
(1.68)^{*}\end{array}$ \\
\hline GDP pc & & $\begin{array}{l}0.011 \\
(0.56)\end{array}$ & & $\begin{array}{l}0.009 \\
(0.47)\end{array}$ \\
\hline HR & $\begin{array}{l}1.206 \\
(8.74)^{* * *}\end{array}$ & $\begin{array}{l}1.166 \\
(6.89)^{* * *}\end{array}$ & $\begin{array}{l}1.263 \\
(8.56)^{* * *}\end{array}$ & $\begin{array}{l}1.229 \\
(6.86)^{* * *}\end{array}$ \\
\hline CZ & $\begin{array}{l}1.341 \\
(3.82)^{* * *}\end{array}$ & $\begin{array}{l}1.344 \\
(3.81)^{* * *}\end{array}$ & $\begin{array}{l}1.028 \\
(2.99)^{* * *}\end{array}$ & $\begin{array}{l}1.035 \\
(3.00)^{* * *}\end{array}$ \\
\hline EE & $\begin{array}{l}2.786 \\
(20.94)^{* * *}\end{array}$ & $\begin{array}{l}2.723 \\
(14.54)^{* * *}\end{array}$ & $\begin{array}{l}2.829 \\
(20.80)^{* * *}\end{array}$ & $\begin{array}{l}2.777 \\
(14.57)^{* * *}\end{array}$ \\
\hline HU & $\begin{array}{l}1.822 \\
(6.79)^{* * *}\end{array}$ & $\begin{array}{l}1.850 \\
(7.08)^{* * *}\end{array}$ & $\begin{array}{l}1.715 \\
(6.52)^{* * *}\end{array}$ & $\begin{array}{l}1.739 \\
(6.73)^{* * *}\end{array}$ \\
\hline LV & $\begin{array}{l}1.986 \\
(18.22)^{* * *}\end{array}$ & $\begin{array}{l}1.942 \\
(14.13)^{* * *}\end{array}$ & $\begin{array}{l}1.984 \\
(18.32)^{* * *}\end{array}$ & $\begin{array}{l}1.947 \\
(14.38)^{* * *}\end{array}$ \\
\hline LT & $\begin{array}{l}2.063 \\
(15.08)^{* * *}\end{array}$ & $\begin{array}{l}2.018 \\
(12.40)^{* * *}\end{array}$ & $\begin{array}{l}2.065 \\
(15.10)^{* * *}\end{array}$ & $\begin{array}{l}2.028 \\
(12.57)^{* * *}\end{array}$ \\
\hline PL & $\begin{array}{l}1.990 \\
(10.98)^{* * *}\end{array}$ & $\begin{array}{l}1.988 \\
(10.84)^{* * *}\end{array}$ & $\begin{array}{l}2.027 \\
(10.76)^{* * *}\end{array}$ & $\begin{array}{l}2.025 \\
(10.61)^{* * *}\end{array}$ \\
\hline RO & $\begin{array}{l}-0.183 \\
(1.23)\end{array}$ & $\begin{array}{l}-0.168 \\
(1.14)\end{array}$ & $\begin{array}{l}-0.134 \\
(0.87)\end{array}$ & $\begin{array}{l}-0.122 \\
(0.80)\end{array}$ \\
\hline SK & $\begin{array}{l}0.197 \\
(0.68)\end{array}$ & $\begin{array}{l}0.213 \\
(0.75)\end{array}$ & $\begin{array}{l}0.071 \\
(0.26)\end{array}$ & $\begin{array}{l}0.086 \\
(0.32)\end{array}$ \\
\hline SI & $\begin{array}{l}2.819 \\
(8.93)^{* * *}\end{array}$ & $\begin{array}{l}2.759 \\
(7.61)^{* * *}\end{array}$ & $\begin{array}{l}2.603 \\
(8.50)^{* * *}\end{array}$ & $\begin{array}{l}2.557 \\
(7.52)^{* * *}\end{array}$ \\
\hline _cons & $\begin{array}{l}3.987 \\
(24.57)^{* * *}\end{array}$ & $\begin{array}{l}3.982 \\
(23.95)^{* * *}\end{array}$ & $\begin{array}{l}4.302 \\
(15.65)^{* * *}\end{array}$ & $\begin{array}{l}4.294 \\
(15.31)^{* * *}\end{array}$ \\
\hline$R^{2}$ & 0.01 & 0.88 & 0.02 & 0.88 \\
\hline$N$ & 185 & 185 & 185 & 185 \\
\hline
\end{tabular}

Note: Data is missing for FYR Macedonia.

Figure A-6

Predicted values: educational expenditures

(using least squares dummy variable estimator) 


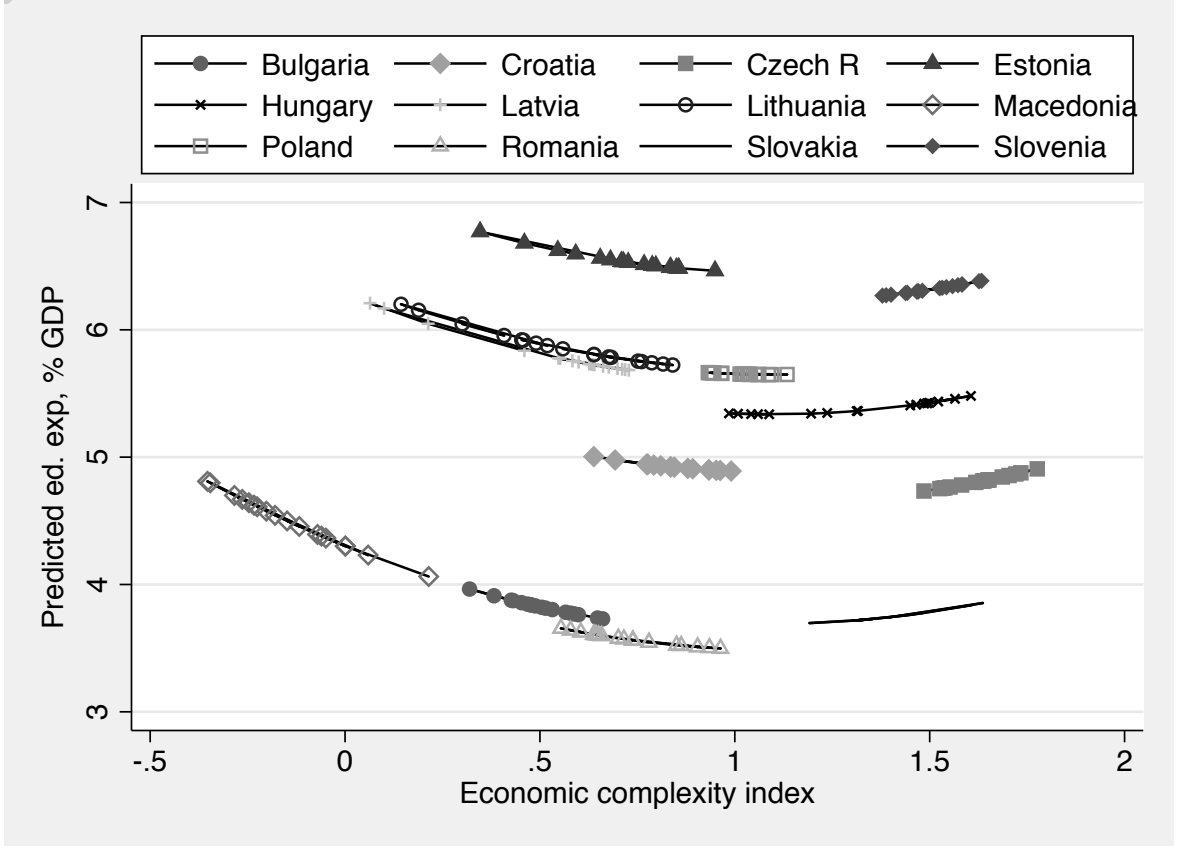

